\title{
Dequantifying diversity: affirmative action and admissions at the University of Michigan
}

\author{
Daniel Hirschman \\ University of Michigan \\ dandanar@umich.edu \\ Ellen Berrey \\ University of Denver \\ Fiona Rose-Greenland \\ University of Chicago \\ fargreenland@uchicago.edu
}

\begin{abstract}
To explore the limits of quantification as a form of rationalization, we examine a rare case of dequantification: race-based affirmative action in undergraduate admissions at the University of Michigan. Michigan adopted a policy of holistically reviewing undergraduate applications in 2003, after the U.S. Supreme Court ruled unconstitutional its points-based admissions policy. Using archival and ethnographic data, we trace the adoption, evolution, and undoing of Michigan's quantified system of admissions decision-making between 1964 and 2004. In a context in which opponents of the system had legal avenues to engage a powerful outside authority, we argue that three internal features of the University's quantified admissions policy contributed to its demise: its transparency, the instability of the categories it quantified, and the existence of qualitative alternatives. Our analysis challenges the presumed durability and inevitability of quantification by identifying its vulnerabilities and suggests that quantification should be understood as a matter of degree rather than a simple binary.
\end{abstract}

\section{Keywords}

Quantification, Organizational Routines, Rationalization, Race, Gratz, Grutter 


\section{Introduction}

This is a story about the limits of quantification. When does quantification fail to serve as a reliable tool for buttressing bureaucratic authority? Beginning with the foundational work of Max Weber and Georg Simmel, sociologists have studied the increasing rationalization of society associated with the expansion of bureaucracies. A more recent tradition, associated with the work of Ted Porter (1995) and Wendy Espeland (1998), emphasizes quantification as one of the foremost tools of rationalization. Quantification, at least in principle, allows bureaucrats to offload the political responsibility of making decisions onto the quantitative tools and thus shield themselves from criticisms of bias (Porter 1995). We examine a rare case in which a system of quantified decision-making was implemented, challenged, and then replaced with a more explicitly qualitative, subjective system: the dequantification of affirmative action in admissions at the University of Michigan. The University's treatment of merit in undergraduate admissions decisions and the design of the law school admissions policy, which survived legal challenge, provide points of comparison. This analysis highlights the inadequacy of binary conceptions of quantification, and sheds light on the instability of quantification - that is, characteristics of a system of quantified decision-making that may not hold up to outside pressure.

To date, scholars of quantification have largely taken for granted this protective power of numbers. They have not explored instances in which quantification might fail to shield expert decision-making. Rather, existing research tends to focus on the consequences of new and successful forms of quantification from credit scoring (Marron 2007; Poon 2007) to university rankings (Espeland and Sauder 2007) to standardized criminal sentences (Espeland and Vannebo 2007). In contrast, we explore features of quantification that make it weak. We ask: What makes a system of quantification more vulnerable to challenges and less capable of providing an 
authoritative aura of objectivity? What can we learn about the component parts of quantification by examining its undoing?

To gain leverage on these questions, we examine undergraduate admissions at the University of Michigan. In the 2003 Gratz v. Bollinger case, in a 6-3 decision, the U.S. Supreme Court ruled that the University's College of Literature, Science, and the Arts (LSA) could no longer make quantified decisions about applicants based on their race. It deemed the University's points-based policy of undergraduate admissions unconstitutional for its coarse and mechanistic implementation of race-based affirmative action. At the same time, in the companion case Grutter v. Bollinger, in a 5-4 decision, the Court upheld the admissions policy used by the University's law school, which relied more heavily on expert judgment. Subsequently, the undergraduate college adopted an admissions policy modeled after the law school's approach. Here, a mechanistic system of quantification provided so little protective objectivity that, in the end, it was explicitly abandoned - reversing the usual trend.

To make sense of this outcome, we use archival and interview data to trace the history of undergraduate admissions at Michigan from 1964 to 2004, with a focus on the University's use of race and merit in admissions. During this time, the University came to rely increasingly on numbers. By the 1990s, it had fully quantified its admissions process, calculating decisions solely on numeric scores, eventually adopting a points-based system called the Selection Index. Conservative activists identified this policy as unlawful and began a legal challenge against the University. In the wake of the Court's decisions, the University abandoned its points-based policy for a process that administrators described as "holistic, individualized review."

Drawing on the case of affirmative admissions at Michigan, we conceptualize dequantification as a process that has several component parts and admits to degrees. 
Specifically, dequantification is one possible outcome in situations in which a decision-making process is quantified and then that quantified system is challenged. Here, we discuss the elements of the case that led to dequantification: three internal features of the system of quantified admissions and important conditions characterizing the relationship between that system and its larger political environment. Theorizing from a single case allows a deep exploration of particular dynamics, but it necessarily entails speculative conclusions. We hope these three elements will usefully transpose, mutatis mutandis, to help explain similar contests over quantified decision-making in other contexts.

First, Michigan's fully quantified system of undergraduate admissions had a great deal of transparency, so that non-experts could easily understand it, in contrast to a technically complex and opaque quantified system of decision-making. Second, Michigan's admissions policy was built on race, which is a contested or stigmatized social material. This contributed to the vulnerability of the system. The University's practice of uniformly standardizing applicants according to their racial group membership violated critics' sensibilities and could be interpreted as conflicting with the complicated jurisprudence of race in the United States. Third, the University used decision-making rules that could be replaced with a qualitative alternative, in this case, holistic review. Such review was practically feasible, professionally legitimate, and as Grutter established, lawful. This contrasts with decision-making routines that must be quantified, as when a court's needs to calculate monetary compensation for difficult-to-quantify objects such as nature (Fourcade 2011) or a child's life (Zelizer 1985).

In addition to these internal features, a few conditions facilitated the challenge to quantification at Michigan. Quantified decision-making systems embedded in organizational processes - in this case, admissions decisions - are commonly subject to oversight by authorities 
that have some power over the decision-makers, and there often exist policy routes to engage that oversight. As a public university, Michigan was subject to both the state Freedom of Information Act (FOIA) and the Equal Protection Clause of the U.S. Constitution. These laws enabled politically mobilized challengers to pry open Michigan's quantification and bring the admissions policy under the purview of the courts, which in turn could pass judgment and force changes in organizational practices. These various features and conditions of quantification were interconnected in the case of Michigan's undergraduate admissions policy. For instance, the legibility of the policy influenced the selection of Michigan as a target by anti-affirmative action activists and the eventual outcome at the Supreme Court.

The failure of Michigan's quantified admissions practices to withstand outside scrutiny in Gratz is made even more puzzling through a comparison with Grutter. The same Court ruled on both cases, and the same political actors, marshaling the same political, cultural, and economic resources, faced off in both cases, in the same context of mixed public opinion about affirmative action and the growing power of the anti-affirmative action movement. Yet the law school's admissions policy passed constitutional muster. The main difference between the two cases was the quantification of admissions. The features and conditions we identify in our analysis help to provide an organizationally grounded explanation of how Gratz was contested (although they alone cannot explain why Michigan lost that case in court).

In addition to the comparison between Gratz and Grutter, we also take advantage of another point of contrast within the undergraduate admissions system: the relative stability of the quantification of merit in Michigan's admissions decisions. Standardized test scores and grade point averages (GPAs), as quantified inputs, are fairly transparent but are not based on contested or stigmatized social material, as there is widespread (though not complete) acceptance that they 
measure aptitude sufficiently well to inform admissions decisions. The University's continued use of quantified measures of merit after Gratz highlights the partial character of dequantification.

Our analysis thus suggests that both quantification and dequantification may be piecemeal processes. Following the 2003 Supreme Court decision, the University did not entirely eliminate numbers from admissions decision-making. Test scores and GPAs remained core components of decision-making under the new policy. These insights help to refine scholarly conceptions of how organizations manage quantification. Quantification is neither absolute nor a simple binary. When an organization quantifies decision-making, it does so on a continuum, ranging from the consideration of quantitative inputs to entirely mechanical decision-making.

While the primary objective of this article is to refine theories of quantification, it also advances the study of inequality by attending to cultural processes of meaning-making in organizational contexts. Affirmative action is the quintessential (and the most politicized) organizational intervention for addressing racial inequality in the U.S (Hochschild 2002; Skrentny 1996). Affirmative action entails both identification and rationalization - two cultural processes that are fundamental to both the production and alleviation of inequality (Lamont et al 2013). Specifically, affirmative action rests on the racialization of individuals' identities and on bureaucratic measures to facilitate integration, made all the more consequential through the sanctioning of the state. Despite academic and political interest in affirmative action in admissions, only a few studies have investigated its historical emergence (Stulberg and Chen 2014; Berrey 2015) or its implementation in practice (Karabel 2005; Steinberg 2002; Stevens 2009). Our analysis demonstrates that organizational attempts to rationalize the reduction of inequality are riddled with a tension between standardization (with its implicit logic of merit and 
neutrality) and redistribution (with its logic of justice and culturally-specific identification). Organizations normalize this tension through their pragmatic routines of evaluation.

This article proceeds as follows. We first present a framework that synthesizes existing research on quantification and organizational decision-making to produce a useful theoretical vocabulary. We then provide necessary background on the history of college admissions and the legal and political debates over affirmative action. Following a summary of the research design and methods, we proceed to an extended analysis of the case of undergraduate admissions at Michigan. We conclude with a brief discussion of other cases that illustrate the spectrum of quantified decision-making.

\section{What is quantification?}

Quantification, following Espeland and Stevens (2008: 402), is "the production and communication of numbers." Contemporary works on quantification document the proliferation of quantification, from the $19^{\text {th }}$ century "avalanche of printed numbers" (Hacking 1982) to cutting edge techniques in the valuation of non-market goods (Fourcade 2011; Beckert and Aspers 2011). Much of this literature addresses the causes and consequences of particular quantifications. More synthetic works (e.g., Espeland and Stevens 1998; 2008) emphasize the important effects of quantification. While a few studies of quantification have examined partial resistance to new forms of quantification (e.g., Espeland 1998; Huault and Rainelli-Weiss 2011), none have considered situations in which quantification fell apart. 
Existing case studies of successful quantifications suggest a tentative principle: that numbers, even bad numbers, drive out no numbers. ${ }^{1}$ Once in place, quantification does not seem to yield easily, except perhaps to a "better" quantification, no matter how "bad" the critics allege the system to be. Much like Weber's (1958) iron cage of rationality, quantification endures. Even though college administrators believe law school rankings to be flawed or illegitimate, they feel compelled to compete to raise their numbers (Espeland and Sauder 2007). Similarly, the history of debates around gross domestic product are rife with calls to improve the statistic, but no calls to abandon the practice of quantifying economic performance entirely (Hirschman 2015).

In order to investigate unstable features of quantification, we turn to Espeland and Stevens (2008) who argue that the durability of quantification rests in both its internal construction and its context. Drawing on the tradition of actor-network theory, they explain that systems of quantification are built on networks of heterogeneous actors: the people and organizations that produce the numbers, the things or individuals quantified, routines and techniques of calculation, physical media (forms, computers, calculators), end users, and so on. ${ }^{2}$ Numbers gain authority depending on how well the networks among objects and humans are constructed. When well-established, the networks that comprise a system of quantification "become so sturdy they are no longer disputed or subject to disassembly" (Espeland and Stevens 2008: 421). Although we do not explicitly employ the vocabulary of actor-network theory, our analysis can be understood as an extension and specification of Espeland and Stevens' argument, as we look to the construction of quantification in context to understand how the networks surrounding numbers can become less resilient.

\footnotetext{
${ }^{1}$ This formulation is modeled after Gresham's Law, an economic principle dating back to the $16^{\text {th }}$ century which states "bad money drives out good."

${ }^{2}$ On actor-network theory, see Latour 2007.
} 
To understand the potential weaknesses of quantification, we examine numbers as pragmatic tools for guiding decisions mired in power dynamics. This is especially evident when expert authority comes under siege. Porter (1995) found that when the Army Corps of Engineers faced criticism from policymakers, the government engineers adopted cost-benefit analysis (CBA) to strengthen their arguments in favor of particular projects. No longer did these projects seem to be simply the engineers' favorites, they now appeared the most beneficial for the least cost. With $\mathrm{CBA}$, the engineers could mask potentially controversial decisions with the appearance of objectivity and rigor (see also Alder 2002, Jasanoff 1991). Porter (1995: 8) usefully summarizes the power of quantified decisions: "A decision made by the numbers (or by explicit rules of some other sort) has at least the appearance of being fair and impersonal. ... Quantification is a way of making decisions without seeming to decide. Objectivity lends authority to officials who have very little of their own." Similarly, Espeland (1998) observes that elites who depend on the approval of powerful outsiders find quantitative decision techniques particularly advantageous.

Systems of quantified decision-making promise mechanical objectivity: anyone applying the system should produce the same decision. The expertise inherent in the system replaces individual judgment. This raises the puzzle of why Michigan's quantified admissions policy failed to protect admissions officers' bureaucratic authority.

\section{Quantification and dequantification as process}

To understand this puzzle, we argue that quantification itself must be understood as a matter of degrees. Much of the existing literature implicitly treats quantification as a binary process: systems move from not quantified (holistic, judgmental) to quantified (mechanical, 
seemingly objective), and researchers examine the consequences of that binary shift. For example, Poon (2007) examines how lending changes when loan officers' judgment is replaced with quantitative credit scoring. Similarly, Espeland and Sauder (2007) examine transformations in legal education when the introduction of quantitative rankings. While recent research has skillfully demonstrated that the effects of a particular form of quantification may vary by organizational and national context (Christin 2015), the fact of quantification itself is still treated as an implicit binary: quantified or not.

Here, we develop a framework for conceptualizing the component parts of quantification. This framework directs attention to key processes of standardization that are necessary for quantification and thus can potentially act as sites of power struggles and, thus, vulnerability. Our framework also highlights quantification and dequantification as processes, rather than binaries. Analytically, the initial step of quantification is the division of the world into distinct types or kinds (of experiences, of people, of anything). This is categorization - the development of a system of discrete, bounded bins into which particular cases can be coded. ${ }^{3}$ This imperfect process lays the groundwork for quantification (Bowker and Star 2000). After categorization, rules of classification come next: guidelines for assigning a particular case to a generic category (Garfinkel 1967). The guidelines for classification can range from tacit and ad hoc to formal and clear cut.

Classification enables enumeration, or the counting of particular kinds (people or otherwise). It also makes possible valuation - the process of attaching numeric values to

\footnotetext{
${ }^{3}$ Following Goffman (1974), science studies scholars sometimes refer to this process as framing (e.g., Callon 1998).
} 
categories. ${ }^{4}$ Specifically, valuation refers to the attachment of numbers that measure, not just numbers that mark, such as addresses on a house (Espeland and Stevens 2008: 407-410). Valuation makes categories and cases commensurable - comparable on a single scale (Espeland and Stevens 1998). ${ }^{5}$

A system of quantification is composed of formal guidelines for categorizing social material, classifying individual cases, and assigning numeric values. Such a standardized system generates numeric outcomes. We emphasize systems of quantification to highlight how these steps are integrated into decision-making, in place of the more vague, standalone term "quantification." These systems commonly build on already existing quantifications as well as past efforts at categorization and commensuration (cf., Holm 2007).

This conceptual framework is instructive for understanding quantification as a tool for organizational decision-making. Modern organizations quantify voraciously. Producing those numbers requires work. Categories must be designated and differentially valued and guidelines for classification must be implemented. Organizations commonly rely on systems of quantification to make decisions, but vary in the degree to which they integrate quantification and decision-making. At one extreme, organizations have routines (Pentland and Feldman 2005) that consult systems of quantification in decision-making but incorporate these systems in nonmechanistic ways. Often, these routines rely on quantifications that, as "truths of nature" or "facts of the matter," are supposed to capture a natural or social process. For example, employers look at measures of inflation, like the Consumer Price Index (CPI), when determining

\footnotetext{
${ }^{4}$ This usage contrasts somewhat with the economic, cultural, and semiotic understandings of valuation present in the literature (Graeber 2001, Lamont 2012).

${ }^{5}$ Categorization and classification are common social processes and they take place even without valuation. For example, in a taxonomy of species, the archetypical categorization (Foucault 1994, Bowker and Star 2000), no species is explicitly "more" or "less" than any other.
} 
employees' raises (Stapleford 2009). The importance of the CPI comes from its perceived objective measurement of economic conditions, but it may be one of many inputs into a messy process.

In a somewhat more mechanical form of decision-making, organizations rely on numbers specifically tailored to the decision at hand. For example, the SAT and consumer credit scores are systems of quantification that are closely connected to specific decisions (admissions and lending). While someone may care about the ability of quantified inputs to measure an underlying reality (e.g., does the SAT really capture academic ability?), such inputs tend to be justified as valid predictors of behavior, such as college graduation, rather than as accurate representations of nature (Lemann 1999, Zwick 2004). Similarly, online news editors examine quantitative measures of online success (especially "clicks") to determine which stories to promote on the front page of their websites (Christin 2015).

Finally, at the other extreme, some organizational decision-making is entirely quantified. It rests on explicit quantitative decision rules that use a calculation to generate a decision mechanistically, such as failing a student on a multiple-choice exam or, as this paper shows, admitting a student to college based on a mechanical tallying of grades, test scores, and other factors. The final outcome of a system of quantified decision-making may be a number, such as a monetary award in a lawsuit based on a calculation of damages (Fourcade 2011), or it may be a binary, yes/no decision, such as choosing to build a dam (Espeland 1998). A system of decisionmaking is more or less quantified depending on the extent of standardization and valuation. A highly quantified system consults numerous categories, has extensive rules for classifying people or things in those categories, assigns consequential numeric values, and relies heavily on numeric outcomes achieved through quantitative decision rules. 
This conceptual framework, and its foregrounding of the spectrum of quantified decisionmaking, suggests that quantification may be undone in a variety of ways. Dequantification, then, refers to the elimination of an established quantitative practice or routine in favor of a qualitative one. Quantitative decision rules might be eliminated, so that decisions are no longer based on mathematical calculations but some set of numbers may still be consulted. Dequantification could involve the removal of the numeric values assigned to certain categories but the continued use of those categories. In its most radical form, a successful challenge could entail the rejection of the fundamental categorizations and classifications upon which the valuation is based. Just as the quantification of decision-making is a spectrum, so too is dequantification.

Following the logic used by Porter (1995) and Espeland (1998) regarding the power of numbers to buffer authority, the more quantified a decision is, the more objective it should seem and the harder it should be to challenge. Routines that simply consult numbers should be seen as less objective than fully mechanical quantitative decision rules. For our case, as Michigan increasingly quantified its admissions decisions between 1964 and 1998, we would expect that the University's policy would become ever more invincible.

Contrary to these expectations, the legal challenge to affirmative action at the University of Michigan directly attacked the objectivity of its quantitative decision rules: the challengers argued that these rules violated the law, above all else, and also disregarded social complexities of race. The challenge to Michigan's admissions practices only makes sense in the context of the admissions objectives the University was pursuing, the legal and political constraints it faced, the contentious complexities of racial categories in the U.S., and the ironies of standardized interventions intended to ameliorate social inequalities. 


\section{Selective college admissions and affirmative action}

Like other important organizational routines, admissions practices enable a university or college to select and secure resources necessary to its survival (cf., Pfeffer and Salancik 1978). Beyond the obvious need to fill classrooms, admissions practices serve the tripartite goals of financial stability, prestige, and legitimacy in the eyes of the public and the state (Killgore 2009: 472; Karabel 2005; Stevens 2009). To balance these complex organizational needs, universities rely on specialized admissions offices, administrators, programs, policies, and routines. Admissions practices are especially important for selective universities - those that reject a large number of applicants. Selective universities vary in the extent to which admissions routines rely on quantification to complete this balancing act and in the systems of categorization they use to evaluate applicants.

Since the 1960s, two attributes of a student body have become very important for the legitimacy of selective universities: academic merit and racial minority representation. The legitimacy imperative around merit was, at heart, a shift in the perception-among admissions counselors, students, and the public - that a respectable educated class should be composed of the most intelligent individuals, not just those from elite backgrounds (Lemann 1999). As such, universities ought to be gatekeepers of the meritocracy, not merely incubators for the children of the wealthy. Even before college rankings began to rely on SAT scores as a measure of the selectivity of the student body, universities used standardized tests to define and identify the most talented students and target them for recruitment. Since the 1980s, selective universities have worked hard to admit these students, motivated in large measure by influential university rankings that prioritize measures of selectivity (percentage of applicants rejected) and academic 
merit (standardized test scores and GPAs) to determine the status of universities and colleges (Stevens 2009, Espeland and Sauder 2007, Sauder and Espeland 2009).

Colleges' efforts to affirmatively admit racial minority students have been far more controversial than their efforts to enroll meritorious students. This controversy is rooted in the long, troubling history of race and racism in the U.S. The very categories and classification schemes that define race have been historically varied and contested since the federal government began racially classifying the population with the first national census in 1790 (Prewitt 2005). Moreover, racial identification has been used primarily for nefarious purposes: as the basis for exploiting and excluding black people and other non-white groups and granting white people access to power, esteem, and resources (Omi and Winant 1994). Such exploitation depends on the categorization of people into different racial groups according to classification rules, the preferential valuing of those deemed white, and the stigmatization of those deemed non-white (Hacking 2005). Although slavery was legally abolished in the late 19th century, the decades of legalized racial segregation and discrimination that followed were legitimized by widely accepted, state-codified racial categories. By the mid- $20^{\text {th }}$ century, political unrest over racial inequality led to consequential legal restrictions on the use of race in organizations' decision-making. With the passage of the U.S. Civil Rights Act of 1964 and subsequent legislation, universities and other organizations could no longer legally discriminate based on race.

Affirmative action emerged in this period as a strategy of evaluation that allocates resources to racial minorities-African Americans in particular but also Latinos and Native Americans - and promotes their pro-active inclusion in the workplace (Skrentny 2002) and at colleges and universities (Stulberg and Chen 2014). By the late 1970s, most elite universities had 
such a policy to further the social justice agendas of equity and diversity and enhance universities' public credibility "especially among non-elite populations” (Killgore 2009: 480). Affirmative action in admissions ("affirmative admissions", cf., Skrentny 2002) entails proactive efforts to increase the likelihood that racial minorities attend and graduate from universities and colleges. In admissions decisions, it gives favorable treatment to members of certain racial or ethnic minority groups above and beyond what a university or college designates as evidence of academic qualifications of merit. Affirmative admissions also can occur in recruitment, advertising, scholarships, and academic support programs.

Affirmative action has long been embroiled in political controversy. The debate centers on the fact that universities make evaluative decisions about scarce resources-slots in an entering class and financial aid — by racializing individuals and deliberately valuing minority status. The liberal defense of affirmative action argues that race-conscious decision-making achieves important societal goals. Supporters initially drew on a discourse of remedying inequality but, since the 1978 Regents of the University of California v. Bakke Supreme Court case, have stressed the value of achieving diversity (Berrey 2015).

The popular conservative or libertarian position against affirmative action initially emphasized white supremacy but, by the 1980s, adopted a discourse of "colorblindness" to assert that any deliberate recognition of racial categories is tantamount to racial discrimination (MacLean 2006). Supporters of colorblindness call for the complete elimination of affirmative action - or, in their oppositional terms, "racial preferences." Some propose that the government altogether stop racializing individuals by removing questions about race from the Census and other surveys.

Conservative activists have mobilized litigation and state referenda to contest public 
universities and public employers' policies of affirmative action. Litigation brings in the outside authority of the U.S. judiciary. The courts, which have become increasingly conservative since the 1970s, have narrowed the conditions under which it is acceptable to consider race in such decisions as hiring, college admissions, and school enrollment (Anderson 2002; Nelson et al. 2008). Notably, federal judges, with Republican appointees taking the lead, have applied the most rigorous type of constitutional review, called "strict scrutiny," to racial classifications used by state programs to determine their legality under the 14th Amendment to the Constitution (Skrentny 2002). If a public institution, such as a university, relies on racial classifications, it must demonstrate that it is using those classifications without malicious intentions. ${ }^{6}$ In particular, the courts have rejected racial quotas (the use of numeric goals based on racial classifications) as discriminatory, even those intended to remedy racial injustices. The question of strict scrutiny was raised in Gratz, Grutter, and again most recently in Fisher v. University of Texas at Austin (2013), in which the Supreme Court allowed affirmative admissions to continue but added an ever higher burden of proof for universities that wish to practice it.

The ability of opponents of affirmative action to leverage legal mechanisms proved instrumental in the dequantification of Michigan's admissions policy. This ability was predicated not only on access to resources, but also on framing the argument such that race and merit were constructed as fundamentally different categories. Producing "race" as a problematic category one that threatened the legitimate work of the "merit" category - turned out to be a powerful rhetorical line for opponents of affirmative admissions.

\footnotetext{
${ }^{6}$ Public colleges and universities are subject to the $14^{\text {th }}$ Amendment's ban on discriminatory government action. All colleges and universities that receive federal funds (and most do) are held to prohibitions on racial discrimination under the Equal Protection Clause of the $14^{\text {th }}$ Amendment.
} 


\section{Research design and methods}

This is a theory-driven, historical-ethnographic study of a single case: admissions at the University of Michigan. We treat admissions as an organizational routine - an interrelated network of "abstract understandings, specific performances and artifacts" (Pentland and Feldman 2005: 794). Following Karabel (2005: 559, italics in original), we define admissions policies as "the criteria (academic, cultural, personal, etc.) that govern decisions of inclusion and exclusion, the procedures for assessing applications, and finally the practices of the office of admissions, which may not correspond to the official criteria and procedures." The study focuses on the decision rules for evaluating applications, not the details of the entire admissions process.

Our theoretical interest in the power of quantification drove the case selection, framed the research question and puzzle, shaped our expectations, and directed attention to relevant evidence (Espeland 2009). The selection of Michigan builds from Luker (2008), who argues for theoretically sampling "data outcroppings"-rich sites where we expect many insights can be found based on past theory. Similarly, Stinchcombe (2005), Small (2009), and Burawoy (1998) advise that ethnographic and historical research makes the most headway by studying cases with extreme or rare outcomes.

Case studies are useful for establishing the existence of a practice (Glaser and Strauss 1967; Small 2009) and following the evolution of that practice through theory-driven process tracing (Gerring 2006). Our analysis reconstructs the series of events within the case that drove quantification and dequantification. We consider the University's reiterated problem (Haydu 1998) of "creating a class" of undergraduates (Stevens 2009) in four discrete periods of time (1964-1978, 1978-1998, 1998-2003, and 2003-2004). These four periods are distinguished by changes in the "organizational thinking" within the institution (Douglas 1986) about race, merit, 
admissions, and quantified decision-making.

We develop an explanatory argument through an iterative process of analyzing concrete evidence and reconsidering theory. The analysis entails both deduction from general theory and induction from detailed observation and so, like other analyses that use theory-driven process tracing, it generates "highly specific propositions" based on "highly specific observations" (Gerring 2009: 118). To refine our understanding of the chain of causal processes that propelled quantification and dequantification, we draw from theory to consider factuals and counterfactuals, most notably by comparing the contention around the quantification of race to the relatively stable quantification of merit.

The research design relies on logical inference rather than statistical generalizability, so it is best suited to generalizing "up" to higher orders of abstraction rather than "across" to a large population of nearly identical cases (Luker 2008). In the discussion, we extrapolate the argument to a few alternate cases in which quantification was highly contentious and failed in some respect: credit scoring, blood quantum laws, and monetary compensation in lawsuits. Following a case-study logic, we added these cases sequentially for the analytic purpose of challenging, confirming, and refining our argument (Espeland 2009, Small 2009) rather than to document the prevalence of dequantification or show its variation. In the discussion section, we show how insights derived from the Michigan case can be transported to help explain the outcomes of those cases.

Evidence for this study includes archival research, interviews, ethnographic fieldwork, and textual analysis. Chronologically, the data collection began with the second author's ethnography of affirmative admissions at Michigan between 2002 and 2005. She conducted a total of 31 formal interviews with University officials and activists as well as participant 
observation of political activities surrounding the Gratz and Grutter litigation and, following the Supreme Court's decisions in 2003, activities of the Office of Undergraduate Admissions such as staff training for the new holistic admissions policy (Berrey 2015). We subsequently collaborated to design our study of dequantification. We conducted extensive archival research, examining the University's publications and promotional materials spanning a forty-year period as well as internal organizational documents stored in the Bentley Historical Library. The data collection focused especially on policy memos outlining the admissions process as well as internal correspondence between the Office of Undergraduate Admissions and the President's office, the Provost's office, LSA, and other administrative units. These materials provided evidence of the development of affirmative admissions at Michigan and the pressures placed on the admissions office. The analysis relies, too, on close readings of the arguments, rulings, and supporting documents associated with the Gratz and Grutter cases.

\section{Undergraduate admissions at the University of Michigan, 1964-2004}

Over a forty-year period, the University of Michigan adopted an increasingly quantified system of undergraduate admissions and then partially dequantified this system. The University faced changing and cumulative pressures in regards to admissions and its varying objectives of efficiency, selectivity, diversity, minority student enrollment, public legitimacy, and legality. Given the context of political contention in which opponents of the system had legal mechanisms to involve an authority with power over the University administration, three features of Michigan's system of quantification led to its eventual failure: its transparency, its reliance on contested social categories, and decision rules that could be replaced with a qualitative alternative. 
Between 1964 and 1978, the University adopted a two-track system; white students were evaluated based on numeric merit criteria and students of color were evaluated based on a holistic assessment. Between 1978 and 1998, the University adopted separate grids of requirements for minority and non-minority students, with numeric thresholds. In 1998, the University transitioned to the more legible points system.

The Gratz and Grutter litigation took place from 1997 to 2003. Gratz challenged both the grids and the points system and culminated in the Supreme Court's decision that those policies were unlawful. The justices relied heavily on the transparency of the points system and criticized the University's quantification of race as a form of (illegal) quotas; in Grutter, those justices who opposed affirmative action could not make such an argument. Between 2003 and 2004, the University (partially) dequantified undergraduate admissions, substituting its quantitative rules for a new policy of holistic review in the context of continuing pressures for diversity and selectivity and additional legal concerns. Throughout these periods, merit - as measured by standardized test scores and grade point average - was never a particularly controversial category of quantified decision-making.

1964-1978: affirmative action's holistic beginnings

In the first period of affirmative admissions at the University of Michigan, from 1964 to 1978, the University used a two-track system of admissions. Its admissions policy was characterized by the use of quantified measures of merit to evaluate white applicants and the use of holistic, expert judgments of character to evaluate individual racial minority applicants, the vast majority of whom were black. This bifurcated approach to assessment was driven by two 
significant changes that the University made to its admissions routine in the 1960s: increased use of quantified measures of merit and increased emphasis on undergraduate minority recruitment.

In 1959, the College of Literature, Science, and the Arts (LSA), the largest undergraduate program, announced that SAT scores and at least one Advanced Placement exam would be required of all applicants. This change was necessary, according to the LSA Dean, because the University would soon be flooded with applicants as baby boomers came of age. ${ }^{7}$ Soon thereafter, the University inaugurated its first affirmative admissions program. While the University had quietly, and without much controversy, admitted small numbers of non-white students since the 1950s, President Harlan Hatcher made affirmative admissions a priority. In a 1963 report to the faculty, he asserted that the University had a duty to recruit and retain "deprived" students, who he described as capable of academic work at Michigan "once the handicaps of poor training have been removed." Inspired by the demands of the black civil rights movement, university leaders around the country were becoming more aware of racial inequality (Stulberg and Chen 2014).

With the Opportunity Awards Program (OAP), the University adopted new evaluative routines based on a new organizational logic. It began to use racial categories to define students and to assign an unprecedented cultural and social worth to minority students. Announced in January 1964, OAP was a scholarship program for students who were academically talented but

\footnotetext{
${ }^{7}$ Annual Report to the Regents, pp. 71-72, September 1959, folder "Regents," box 14, University of Michigan Office of the President (hereafter Hatcher papers). Bentley Historical Library.

${ }^{8}$ Annual Report to the Regents, September 30, 1963, folder "Speeches," box 57, Hatcher papers. Bentley Historical Library.
} 
whose socio-economic background was one of "deprivation and disadvantage." This was a logic of redistribution, justified with a rhetoric of creating opportunity to remedy disadvantage (Berrey 2011). Although University administrators downplayed the treatment of race, in practice, OAP served primarily black students, who comprised $85 \%$ of the first four OAP classes. ${ }^{10}$ For administrative purposes, all minority applicants were understood to be part of the OAP stream.

With OAP, the University had a two-track system for admissions. Mainstream applicants were expected to have a 3.3 high school GPA as well as SAT scores in the top $25 \%$ in order to be admitted. Racial minority students, and disadvantaged white students, were judged less mechanically. Officially, OAP students needed to have a high school record of B average or better; letters of recommendation from high school teachers; a "commendable personal record"; and "proven membership in a disadvantaged group." 11 OAP included, importantly, holistic admissions decisions. These applicants were recruited separately through intensive personal contact and evaluated based on altered admissions criteria, with "promise" weighted over numerical scores (Greenland, Chen and Stulberg 2010). ${ }^{12}$ If they fell short of the numerical targets, they were admitted if their letters and personal records indicated promise as defined by recruiters. Administrators publicly explained the program's criteria: “There is considerable evidence that [disadvantaged students are] not as accurately judged by test score devices ... [and]

\footnotetext{
${ }^{9}$ Ralph Gibson's report to President Robben Fleming and SACUA, December 30, 1968, folder "Steering Committee on the Development of Academic Opportunities," box 1, John Chavis papers. Bentley Historical Library.

10 "Need to recruit poor cited at U-M," Ann Arbor News, 1/11/67

${ }^{11}$ Opportunity Award Program establishment memo, April 22, 1970, folder "Opportunity Award Program," box 15, University of Michigan Office of the President Papers (hereafter Fleming papers). Bentley Historical Library.

${ }^{12}$ Vice President for Academic Affairs papers, various memos dated May, 1963 through August, 1964, box 1, VPAA papers. Bentley Historical Library.
} 
that their high school grades are less meaningful than their degree of motivation." 13 In short, the standardized measures of merit used to evaluate mainstream applicants were deemed insufficient to assess disadvantaged students' potential.

Under the early holistic admissions policy, the proportion of minority students grew slowly: in 1967 , less than $1.5 \%$ of the University's 30,000 students were black. That same year, a government audit of the University's compliance with Title VI of the Civil Rights Act criticized the institution as primarily serving "rich white students" (Nelson 1967). By 1969, minority students comprised $3.4 \%$ of the student body. This figure did not satisfy campus activists. Emboldened by campus anti-war demonstrations, students organized the Black Action Movement (BAM) and demanded, among other things, that minority student enrollment be increased to $10 \%$ (Brune 1994). The campus-wide BAM strike, which attracted national attention, marked the first time that the University's admissions procedures became the object of public criticism and discourse. BAM's activism made the category of race and its treatment in admissions decisions much more contentious.

The Board of Regents officially refused BAM's demand, but University leaders implemented a plan that aimed to have minority students constitute $10 \%$ of undergraduate enrollment. To do so, they augmented the existing affirmative admissions infrastructure. In 1970, the Board of Regents voted to triple OAP's budget. ${ }^{14}$ Recruitment procedures were streamlined. One-on-one interviews were still encouraged but no longer required, and rather than relying on just one recruiter, former OAP students were asked to help identify and recruit potential students.

\footnotetext{
13 “Answers to some Frequently-Asked Questions about the expanded Opportunity Award Program at the University of Michigan." University Relations Office memo, April 28, 1970, box 15, Fleming papers. Bentley Historical Library.

${ }^{14}$ From $\$ 980,000$ in 1970 to $\$ 3$ million in 1973-1974. Admissions Office budget data, 1972 and 1973 reports. Archives of the Office of Budget and Planning, University of Michigan Office of the Provost.
} 
The University continued to evaluate test scores cautiously for minority students, sometimes throwing these scores out altogether.

In this first phase of affirmative admissions, the University laid the groundwork for categorizing and classifying students by their racial status and applying different bureaucratic procedures accordingly. Race became a contentious category because of its association with societal inequality. The organizational logic was that race could be made less problematic through affirmative action, which could remedy disadvantage. Merit, as a measure of academic preparation, was largely uncontroversial. This sorting groundwork persisted for decades, as the University quantified its rules for evaluating all applicants.

1978-1998: the rationalization of affirmative admissions

In the 1980s, University administrators retained a two-track system of admissions but began to evaluate the merit of minority students according to the same criteria as non-minority students. They created basic quantitative decision rules for making those admissions decisions. The new decision rules, formalized in grids with numeric thresholds, treated race as a literal plus factor and did so in a very transparent manner, which anti-affirmative action activists discovered and made known to the public in the late 1990s.

The University intensified the quantified aspects of the admissions policy in the face of several new challenges, most notably increased demand for admissions, new pressures to cultivate an image of selectivity, and new legal constraints on the use of race in admissions. Throughout the 1980s, the Office of Undergraduate Admissions (OUA) faced a surge in application numbers. Although several high-ranking administrators preferred qualitative 
assessments of applicants, the office struggled to find a way to process applications more efficiently. ${ }^{15}$ In 1975 , it received 11,060 applications for its freshmen class. In 1980, this number stood relatively unchanged at 11,595 . But by 1985 , OUA received 16,281 applications, a $40 \%$ increase. ${ }^{16}$ Staff members were criticized for making decisions too slowly, ignoring applicants' inquiries, and mismanaging admit data. ${ }^{17}$

This increase in applications presented OUA with reason to be more selective in admissions decisions. Throughout the 1980s, the University of Michigan's national reputation steadily improved. It was precisely during this period of time that published college rankings the "guidebooks" - drew widespread interest, and universities used them to cultivate a class of education consumers (Espeland and Sauder 2007: 9-10). Michigan consistently ranked around 25th in the newly relevant U.S. News and World Report college rankings, with its strong academic reputation somewhat compensating for its selectivity scores, which were low compared to other top schools. ${ }^{18}$

Bakke and the turn to diversity

Meanwhile, Michigan also confronted new legal constraints on its affirmative admissions

\footnotetext{
${ }^{15}$ Letter from Jack Meiland, Associate Dean of LSA, to Vice-President for Academic Affairs Billy Frye, June 25, 1984, folder “Admissions Office, 1983-1984," box 152, VPAA papers. Bentley Historical Library. See also: letter from Robert Holmes, Associate Vice-President for Academic Affairs to Billy Frye, December 10, 1984, folder "Admissions Office, 1983-1984," box 173, VPAA papers. Bentley Historical Library.

16 "Report from the Task Force on Undergraduate Admissions," written by John Chamberlain, July 21, 1986, folder "Admissions Office," box 214, VPAA papers. Bentley Historical Library. ${ }^{17}$ Letter from Billy Frye to Robert Holmes, June 4, 1984, folder "Admissions Office," box 152, VPAA papers. Bentley Historical Library.

${ }^{18}$ US News and World Report, "Sat's, School by School," October 26, 1987, page 90. US News and World Report, "The Best Big School," October 10, 1988, page C6.
} 
policy. In September 1978, University officials held a two-day conference to discuss its admissions procedures and minority recruitment in light of the Supreme Court's decision in the first major legal case on affirmative action and admissions, Regents of the University of California v. Bakke. Alan Bakke, a white man, was denied admission to the University of California's medical school at its Davis campus. He challenged the medical school's policy of setting aside 16 of 100 seats for African-American students.

The Court announced six separate opinions in this very divided decision. Five of the justices determined the UC-Davis policy to be an unconstitutional racial quota. Of those five, Justice Lewis Powell was the only one of who found that race could be considered in admissions decisions. But he also departed from the other four justices, called the "Brennan Four," who considered affirmative action an acceptable means of remedying racial minority disadvantage. In his solo-authored opinion, Justice Powell provided an alternative, non-remedial defense of affirmative action. He reasoned that "diversity" is a compelling goal in admissions decisions because "the robust exchange of ideas" is central to the educational mission and ensues from an environment that is diverse along many dimensions, including but not limited to race and ethnicity. He wrote that an applicant's race or ethnicity could be treated as a "plus factor" in admissions decisions. His opinion was not a majority opinion, but it allowed for the consideration of race in admissions while also placing the most restrictions on the admissions process. Thus, it provided the most restrictive and, therefore, most defensible guidelines for universities with voluntary affirmative admissions programs.

The Bakke decision prompted Michigan to modify both its organizational logic of remedying racial minority disadvantage and its admissions routine of holistically reviewing minority applicants. At a September 1978 conference, administrators articulated an interpretation 
of the ruling was similar to that of universities throughout the country: the race of an individual applicant could be taken into consideration but could not be decisive in a decision (Thelin 2004: 348) and such consideration was for the purposes of fostering diversity. Conference participants also stressed the importance of using standardized test scores and high school GPA for admissions decisions. Doing so, they explained, would ensure compliance with Bakke by subjecting all applicants to the same criteria and it would simultaneously satisfy the University's newfound concerns about selectivity. Subsequently, the University turned away from public discussion of minority enrollment targets. Instead, its public rhetoric emphasized diversity as a social characteristic and treated students as bearers of personal and social qualities that could contribute to the university community (Berrey 2011). In practice, however, the University further quantified its admissions decisions.

The quantification of race

In 1980, following its analysis of Bakke, the University adopted a new policy that relied on both quantified inputs and quantified decision rules, with different standards of evaluation depending on an applicant's racial identity. Specifically, it provided clear threshold criteria for non-minority applicants and "underrepresented minority (Black, Spanish surname, Native American)" applicants, guided by a 3-by-4 grid. In-state non-minority applicants with an SAT score of at least 1000 and a high school GPA of at least 3.5 were admitted. Applicants with scores lower than these thresholds might receive a conditional admission, delayed decision, or rejection. OUA's grid policy included "Guideline Exceptions" with different threshold SAT and 
GPA criteria for underrepresented minorities. A high school GPA of 3.0 and SAT of 850 ensured admission for an underrepresented minority student.

The University's new grid system was informed by an important shift in organizational logic. Gone was the rhetoric that minority students' standardized test scores were insufficient indicators of “promise.” Instead the University operationalized Powell's conception of race as a "plus factor" quantitatively — as a lower quantitative threshold for admitting students of color. The grid system provided clear comparisons between minority and non-minority students.

Through the 1980s, the University modified the grid system, adding more inputs and making the quantitative decision-rules more complex. By 1987, under the direction of Cliff Sjogren, the undergraduate admissions system had an acronym, SCUGA, which stood for School, Curriculum, Unusual, Geography, and Alumni. SCUGA added more nuance to the 19801981 grids. Its basic infrastructure was little altered through 1996. Figure 1 presents the 1996 grid.

\section{[FIGURE 1 ABOUT HERE]}

To process an application, admissions staff calculated what was called a GPA2. First, they created a GPA1 based on applicant's 10 th and 11 th grade academic GPA. ${ }^{19}$ This GPA1 was then modified based on the other SCUGA factors. Each high school received a "School" score of 0 to .5 based on the average standardized test scores (SAT, ACT) of the students who attended the school and the percentage of students who attended college. ${ }^{20}$ Similarly, students' curricular choices ("Curriculum") were ranked on a scale from -.2 to +.4 . These scores were then added to

\footnotetext{
${ }^{19}$ This entire paragraph derives from the 1995 admissions policy (1995 SCUGA) in the Admissions Lawsuit Collection, folder "Defendant Motions," box 14. Bentley Historical Library. ${ }^{20} 1995$ SCUGA p. 2
} 
the recalculated GPA to account for mediating factors such as the difficulty of the school and the curriculum chosen.

Unlike the first grids, SCUGA incorporated other, non-academic, organizational priorities into the calculation of a student's GPA2. A student's "Unusual" personal accomplishment could net them a bonus to their GPA of up to .3 , although relatively few students received this bonus. ${ }^{21}$ Students received a "Geography" bonus for being residents of northern Michigan, rural areas, and some Western and Southern states. Finally, students received a bonus for having an alumnus relative (“Alumni”). Together, this mélange of factors constituted GPA2. Using this quantified system, admissions officers mechanistically calculated admissions decisions: they compared the GPA2 (on the left column of Figure 1) to the student's standardized test score (on the top row) to find the appropriate cell.

With SCUGA, the University continued to treat race in a coarse fashion. It racialized students by assigning them to one of two categories: "majority" (white, Asian American) or "underrepresented minority" (African American, Latino, Native American). For each year, the University produced multiple grids. In 1996, the university created a single matrix that included in-state minority and non-minority students, as shown in Figure 1. According to that grid, an instate, white student with a GPA2 of 3.0 and an SAT of 1100 would be rejected, while an in-state African American with the same scores would be accepted.

Although the decision rules of SCUGA were more complex than the first grid system, they were recognizable and legible based on the written policy. And the inclusion of race within the grids facilitated the easy interpretation of minority status as simply a quantified boost to an applicant's admission chances comparable to better grades or test scores. Admissions director

21 "It is expected there will be no more than 20 to 30 students who would qualify for a "U" factor.” 1995 SCUGA p. 3. 
Sjogren heralded the simplicity and rationality of SCUGA to a national audience. ${ }^{22} \mathrm{He}$ presented the criteria as beneficial, objective indicators that could be easily modified to account for any extenuating circumstances. In an interview with the Ann Arbor News, he cited the "simplistic design" and "the ease with which scales can be adjusted to accommodate more or fewer enrollments, or to place greater or lesser emphasis on individual admission factors."

In the late 1980s, a public controversy erupted over the University's high rate of out-ofstate admissions. Throughout the 1980s, applications from in-state students decreased and by $1987,40 \%$ of the entering class was from outside Michigan. The Michigan public reacted with outrage over the denial of admissions to in-state students with formerly sufficient test scores and GPAs. ${ }^{23}$ For years, OUA field representatives had explained admissions criteria in numerical terms. Now, Michigan residents decried the admissions process and demanded an explanation in numbers. Newspapers profiled Michigan high school graduates whose applications were rejected by the University. Such stories focused on test scores, grade point averages, and other measures of merit as evidence that well-qualified in-state students were not being admitted. An article from The Flint Journal ${ }^{24}$ is exemplary:

Even seniors ranking academically in the top $10 \%$ of their class are receiving admissions rejection notices from the university:

A Grand Blanc High School senior with a 3.88 GPA, out of a possible 4.0, was turned down for admission to the Engineering School.

A Holy Rosary Catholic senior finished third in his class academically with a 3.62 GPA but was rejected for pre-law "due to a large increase in applicants."

\footnotetext{
${ }^{22}$ C. Sjogren, "Additional Measures in the Admissions Process." Paper presented to the College Board meeting, June 1986.

${ }^{23}$ E.g., University of Michigan, Proceedings of the Board of Regents, Mar 1987:1096

${ }^{24}$ Flint Journal, “Top Flint-area students find UM doors closed,” June 11, 1987, page A1.
} 
In their letters of complaint to the University, aggrieved families described the numeric profile of the rejected applicant. Like the OUA counselors, they had come to understand merit-based admissions decisions in quantifiable terms. In fact, the public outcry reveals widespread acceptance of quantified measures of merit. The problem was that those measures did not evenly apply to all applicants.

In a 1987 newspaper article, Sjogren described the University's selectivity and spoke candidly about the standards used by his office: "We turned away 7,000 qualified students this year. That means they had a 3.0 grade-point average and 1,000 or better on the Scholastic Aptitude Test. Those are students who are in the top one-third nationally, and we believe they could have done the work at Michigan." He explained that the average high school GPA for entering freshmen had risen from 3.2 a few years prior to 3.5 or 3.6. "That sets the standard for instruction up higher. The gap has widened, making it more difficult for minority students to keep up." ${ }^{25}$ Minority students' applications were judged differently: "It's no secret that we're taking minorities with lower GPAs than majority students ... We don't go out and tell the world about it, but we're not making a secret of it either." The newspaper article described the SCUGA system and explained how OUA staff used it to make decisions about applications.

From the point of view of admissions administrators, it was perfectly reasonable to quantify their evaluations and to assess students differently based on their racial minority status. The administrators treated this heightened standardization of admissions as efficient, effective, and fair. Nonetheless, the ease of reading affirmative action policy off the SCUGA decision admissions grid played a crucial role in the decision by opponents to challenge affirmative admissions at Michigan. Tracing this process reveals that race and quantified assessments were

${ }^{25}$ Ann Arbor News, “At U-M, getting in gets harder for in-staters," June 7, 1987, page F1. 
disputed, structurally unstable inputs into the admissions process at an early stage, setting the stage for the Gratz and Grutter cases.

Uncovering the "smoking gun"

In the 1990s, anti-affirmative action activists had political momentum and resources to push their cause. Most importantly, they had FOIA, which served as a legal mechanism for producing transparency at Michigan and engaging the external authority of the courts. In December 1995, Carl Cohen, a professor of philosophy at the University, submitted a FOIA request for Michigan's admissions policies. Cohen had been a longtime opponent of affirmative action. ${ }^{26}$ After receiving the SCUGA grids, Cohen wrote up a scathing report and sent copies to the regents and President Duderstadt, noting, "In ten cells in which GPA is 3.0 and above but SAT scores are below 1000, majority applicants are rejected, but minority applicants accepted. ${ }^{27} \mathrm{He}$ contrasted the University's admissions process and its stated policy of nondiscrimination: "Admission practices at The University of Michigan show very marked preferences by race and ethnic category. This is not consistent with our formal profession of strict equality of treatment by race."28

Cohen's report had a tremendous impact on campus and beyond. Opponents of raceconscious admissions used it in support of their national political activities. Republicans in the Michigan State House and Senate held hearings on discrimination and affirmative action at the University and called on Cohen to testify. A group of Republican representatives began

${ }^{26}$ Carl Cohen, Naked Racial Preference: The Case Against Affirmative Action. 1995.

${ }^{27}$ C. Cohen. Racial Discrimination in Admissions at the University of Michigan. p. 3. See also interview with Carl Cohen.

${ }^{28}$ C. Cohen. Racial Discrimination in Admissions at the University of Michigan. p. 10 
recruiting plaintiffs to file a lawsuit challenging Michigan's policies, and they contacted the Center for Individual Rights (CIR) to take charge of the litigation. CIR, a conservative non-profit organization, had recently led the first successful challenge to a university's affirmative action policy since Bakke. In Hopwood v. Texas, the Fifth Circuit ruled that the University of Texas law school could not consider race in admissions decisions, thus rejecting the argument that diversity was a compelling state interest that justified race-conscious admissions policies. This decision prohibited race-conscious admissions in the states of Louisiana, Mississippi, and Texas.

In seeking to expand the scope of Hopwood, CIR settled on Michigan as its next target. The legibility of the SCUGA grids and the interest generated by Cohen's report were instrumental in this choice. As Curt Levy, CIR's director of legal and public affairs, recounted during an interview before the Supreme Court decision was announced,

Ultimately when we started looking at the grids and stuff, it really stood out... $[\mathrm{P}]$ art of the reason [we chose Michigan] was A., you had these plaintiffs ... And B., you already had some P.R. going about it, so we knew we'd get some publicity for the case.... But more than anything else, the grids provided a very graphic representation of, you know, a two-track admission system. ${ }^{29}$

As Carl Cohen described his experience of showing the report to CIR: "They loved it. These grids, one of them says 'Phew, the smoking gun! ${ }^{\prime 30}$ With the FOIA request, opponents of affirmative action brought the grids, with their transparent rendering of the quantification of race, into the public spotlight.

In October 1997, CIR filed two separate legal claims against the University alleging that its admissions policies were unconstitutional. Gratz represented two individuals who had applied for admission to the undergraduate college and were rejected, at least initially. Grutter represented an individual who had applied to and been rejected from the law school.

\footnotetext{
${ }^{29}$ Interview with Curt Levy.

${ }^{30}$ Interview with Carl Cohen.
} 
1998-2003: the points system, overturned

Between Carl Cohen's 1996 report and the October 1997 filings, the University made another substantial change to the format of its admissions policies. For the 1998 admissions cycle, the grids were replaced with the Selection Index, also known as the "points system" (see Figure 2). The new system was designed by a statistician in order to reproduce the decisions made through the SCUGA grids without separating in-state, out-of-state, minority, and nonminority applicants. ${ }^{31}$ The particular quantitative rules for decision-making were changed, but the system of quantification remained essentially intact.

\section{[FIGURE 2 ABOUT HERE]}

Using the Selection Index, applicants were admitted if they accumulated a total of 100 points, of which at least 75 had to come from their academics. ${ }^{32}$ As with SCUGA, the Selection Index relied on a mix of academic and non-academic factors. Students received 20 points multiplied by their $10^{\text {th }}$ and $11^{\text {th }}$ grade academic GPA, up to 12 additional points from their standardized test scores, and more points based on the strength of the curriculum and characteristics of the student's high school. As with SCUGA, students could also receive points for various non-academic factors including Michigan residency, alumni relatives, and exceptional personal accomplishments, along with a single point for an outstanding admissions essay. Finally, the heterogeneous "miscellaneous" category was worth up to 20 points for students from socioeconomically disadvantaged backgrounds, scholarship athletes, and,

\footnotetext{
${ }^{31}$ Deposition of David Hunter.

${ }^{32}$ For details, see "1998 Guidelines for the Calculation of a Selection Index for all Schools and Colleges Except Engineering", Admissions Lawsuit Collection, Box 14, file: "Defendant Motions", Bentley Historical Library.
} 
crucially, underrepresented racial minority students. ${ }^{33}$ By collapsing all categories of students into a single system, the University furthered the transparent comparison of race to other admissions variables.

The points system remained in place virtually unchanged during the period of the Gratz litigation, from 1998 through 2003, as the University believed it unwise to change the policy during the litigation process. ${ }^{34}$ On the defensive, University officials continually denied that they adopted the Selection Index in response to negative publicity surrounding the grids. They argued instead that the points system was a mechanically simpler way of achieving the same objectives. $^{35}$

The Gratz litigation challenged the constitutionality of both the SCUGA grids and the points system. In doing so, it involved the U.S. courts, which exercise constitutional authority over the University. The plaintiffs charged that Michigan's race-conscious undergraduate admissions policies gave explicit preference to racial minority applicants without sufficient justification. In legal terms, they argued that the policy did not pass the test for strict scrutiny. The central legal question in Gratz, as in Grutter, was whether the University's treatment of race in admissions decisions violated the Equal Protection Clause of the Fourteenth Amendment and Title VI of the Civil Rights Act of 1964. In our terms, the litigation contested the University's quantified valuation of underrepresented minority students in its race-conscious admissions decisions.

In both Gratz and Grutter, the burden on the University was to show that its use of racial classifications in admissions both served a compelling state interest and was narrowly tailored to

\footnotetext{
${ }^{33}$ As well as 5 points for men in nursing, and 20 points for a somewhat mysterious "Provost's Discretion" category.

${ }^{34}$ Interview with Chris Lucier.

${ }^{35}$ See Seltzer Deposition, Spencer Deposition, and the Joint Summary of Undisputed Facts.
} 
achieve diversity. Michigan claimed that its policies passed the standard of strict scrutiny by arguing the diversity rationale: that universities should be able to consider race in admissions to ensure diversity because students have better learning and leadership outcomes when they interact with students of other racial and ethnic backgrounds. The University also argued that its undergraduate and law school admissions policies were carefully designed to achieve diversity.

Gratz and Grutter represented the apex of decades of political contestation over the treatment of race in admissions decisions and, more generally, over race-conscious organizational decision-making. They were the first major challenges to affirmative admissions after Bakke to culminate in a Supreme Court decision. The litigants' opposing positions mapped onto the broader social, legal, and political contention concerning race in the U.S. The debate cleaved most sharply between those who believed that organizational decision-making should be colorblind because any consideration of race is tantamount to discrimination (the plaintiffs) and those who believed that race deserves consideration in decision-making for the purposes of achieving diversity (the defendants) or remedying racial inequalities (student-activists who intervened in Grutter at lower levels of the court). While these broader political debates set the stage, the arguments in Gratz focused on the mechanics of affirmative action itself.

Mobilizing the transparency of the points system

Opponents of Michigan's affirmative action policies drew on the transparency of the points system to argue that the University's treatment of race for admissions purposes was unlawful. While the SCUGA grids initially had captured their attention, their legal arguments in Gratz focused on the Selection Index. Crucially, the points system and the 20-point award for 
certain racial minorities made the logic of the policy readily legible and, thus, easy to critique. The plaintiffs' brief stated: "Beginning with the entering class in 1998, mere possession of the specified racial or ethnic status has been enough to entitle an applicant automatically to 20 points out of a total of $150 \ldots$ The existence of a 'two-track' system could not be more apparent."36 The plaintiffs argued that the existence of the 20 points proved that Michigan was calculating admissions decisions using a numeric value based solely on an individual's race - what Powell would describe as the "functional equivalent of a quota." ${ }^{, 37}$ The plaintiffs interpreted the 20 points not as an objective measure of any social reality but as a crude, mechanistic form of racial favoritism. In its defense, the University claimed that the Selection Index, in practice, was implemented in a way that gave individualized attention to all applications, considering "race or ethnicity as one of many factors in admissions." ${ }^{38}$

The Selection Index also captured the Supreme Court's attention during oral arguments. The frequency with which the 20-points award was mentioned is illustrative. The justices, the plaintiff's attorney Kirk Kolbo, and Solicitor General Theodore Olson (who argued for the U.S. Department of Justice as amicus curiae in favor of the plaintiffs) collectively mentioned the terms " 20 points" and " 20 point bonus" a total of 17 times during the arguments..$^{39}$ In contrast, the University's attorney John Payton referenced it only twice and in the same sentence: "the 20 points for race and 20 points for athletics." Payton tried to avoid any discussion of the points system. He typically responded to the justices' questions about the 20 points by speaking, instead, of every application receiving "individualized consideration" and being "read in its

\footnotetext{
${ }^{36}$ Plaintiff's Brief, p. 21.

${ }^{37}$ Bakke, 438 U.S. at 318.

${ }^{38}$ Brief for the Respondents, Gratz, p. 11.

${ }^{39}$ Quotations from the Gratz oral arguments are not footnoted. Quotations from other documents in the Gratz litigation are listed in abbreviated format.
} 
entirety." Payton turned to individualized consideration and expert judgment to defend the University's authority. Michigan's numbers were perceived as a liability, not a strength.

The contentiousness of race

The plaintiffs made their case in Gratz by amplifying the contentiousness of race. They framed Michigan's policy as problematic on the grounds that any use of racial categories in decision-making is socially harmful. As Olson stated during oral arguments, "[The] Court has said that racial preferences, racial stereotyping, which it is, is stigmatizing, it's divisive, it's damaging to the fabric of society, it's damaging to the goal ultimately to eliminate the problems that racial discrimination and racial differences have created." ${ }^{40}$

In response, Michigan invoked the diversity rationale to downplay the contentiousness of race. The University characterized race as problematic but still socially meaningful because it was a basis of division and segregation in society. The University's brief claimed that most students have consequential experiences that follow from their racial status: "Notwithstanding decades of progress, there remain significant differences in our lives and perceptions that are undeniably linked to the realities of race." ${ }^{, 41}$ The brief explained that most students grow up in homogeneous settings and, as a result, have few opportunities for "meaningful interactions across lines of race and ethnicity" before coming to college. Further, the University suggested that racial categorization was congruent with the University's educational mission: "Bringing

\footnotetext{
${ }^{40}$ None of the plaintiffs' attorneys went so far as to argue that race was socially meaningless and should therefore be ignored altogether, as that was not the question before the Court. This rejection of any race-conscious decision is an argument made by some opponents of affirmative action and one that has been increasingly accepted by conservative judges.

${ }^{41}$ Brief for the Respondents, Gratz, p. 25.
} 
together students with different life experiences creates opportunities for rich and vivid exchanges, as students reflect on those experiences in a new context and share their own interpretations of them." 42

At the Supreme Court, numerous debates ensued over the University's quantification of race, centering on whether race was a socially meaningful category that should be valued in decision-making. A question from Justice Stephen Breyer, a liberal justice who ultimately concurred with the majority opinion in Gratz, reveals a moderate distrust of the Selection Index. During oral arguments, Breyer posed a hypothetical scenario: how would the University compare an African-American to a white male athlete from a poor family? He later answered his own question, stating that the applicant "just can't overcome that 20 points - the best he can do is tie." Breyer interpreted the points system as an inflexible thumb on the scale that unfairly favored any given African-American (or, presumably, Latino or Native American) applicant over any given white (or Asian-American) applicant. His comments can be read as skepticism about the University's practice of crudely classifying applicants according to two homogenizing racial categories (majority or underrepresented minority) and assigning them differential numeric values ( 0 points or 20 points).

In response to Breyer's hypothetical scenario and the questions from the justices that followed, Payton argued that admissions counselors would actually read the applications of both the black student and the white student. "They both receive individualized consideration. They're both reviewed in their totality. They both may be sent to the admissions review committee where they get a second reading." The attorney hoped to persuade the justices that the University's

${ }^{42}$ Brief for the Respondents, Gratz, p. 11. 
admissions decisions were predicated on expert judgments, not on rote classification of individuals or mechanical application of standardized decision rules.

Justice Antonin Scalia, in an exchange with Payton, reiterated his concern with the University's standardized treatment of race. Scalia asked if there were any racial minorities who were academically qualified for admission received the 20-point bonus but had been rejected. Payton replied that he did not know. He then cited the record as stating "most of the qualified minority applications do end up getting admitted." He emphasized that this was a by-product of the way the policy was implemented, not an unlawful motive inherently codified in the math. ${ }^{43}$ "[T]he design is not 'Gee, admit all qualified minorities." Payton was attempting to present the 20 points as an important quantitative input, not the linchpin of a rigged, mechanized system. But the exchange between Scalia and Payton was a defining moment in the debate. It foreshadowed the Court's decisions, announced a few months later.

The court's rulings

In the Grutter decision, the Court agreed with the University's position on diversity, upholding Powell's opinion in Bakke as precedent. The ruling meant that universities could continue to consider race in admissions selections as long their policies treat race as one of many

\footnotetext{
${ }^{43}$ Archival records seem to contradict Payton's claims. At least through the mid-1990s, the University's undergraduate admissions policy seems explicitly intended to admit all qualified minority students. See "Admission Policy for Minority Students." University of Michigan Vice Provost for Academic and Multicultural Affairs. Box 20, file "Affirmative Action Ad Hoc Committee 1995-1996." Bentley Historical Library, University of Michigan.
} 
factors and are flexible enough to ensure that applicants are treated as individuals. The Gratz decision, however, found both the grids and the points system unacceptable. ${ }^{44}$

The Court's majority opinion in Gratz, delivered by Chief Justice William Rehnquist, drew on constitutional law and the legibility of the Selection Index to support its findings. In our analytic terms, the opinion concurred with the plaintiffs' position that the category of race was too contentious, too unstable to be evaluated quantitatively. For the Court, the University's undergraduate admissions policy was unconstitutional because it was not designed to treat any individual applicant as a person with unique attributes: "the LSA's automatic distribution of 20 points has the effect of making 'the factor of race ... decisive' for virtually every minimally qualified underrepresented minority applicant." ${ }^{, 45}$ The Court also explained that the automatic distribution of the 20 points was not narrowly tailored to achieve educational diversity. Its directive in Grutter was that race-conscious decisions had to employ a "highly individualized, holistic review of each applicant's file, giving serious consideration to all the ways an applicant might contribute to a diverse educational environment. ${ }^{, 46}$ The Court wanted holistic expertise, not mechanical objectivity.

The Court also rejected the University's argument that the Selection Index was a necessarily simplified system needed to efficiently manage a large volume of applications. The majority opinion stated, "The fact that the implementation of a program capable of providing individualized consideration might present administrative challenges does not render

\footnotetext{
${ }^{44}$ The Supreme Court's decision in Gratz upheld the finding of the U.S. District Court for the Eastern District of Michigan that the SCUGA policy was unacceptable. It overturned the District Court's finding that the points system was acceptable.

${ }^{45}$ Gratz Majority Opinion, p. 23.

${ }^{46}$ Grutter Majority Opinion, p. 4.
} 
constitutional an otherwise problematic system.. ${ }^{, 47}$ According to this reasoning, the University's quantitative decision rules on admissions could be replaced with qualitative ones and still produce good admissions decisions.

Justice Ruth Bader Ginsburg, in her dissenting opinion, interpreted the legibility of the points system quite differently. As she argued that the Selection Index was lawful, she characterized the 20 points as evidence of the University's trustworthiness: "[I]f honesty is the best policy, surely Michigan's accurately described, fully disclosed College affirmative action program is preferable to achieving similar numbers through winks, nods, and disguises.."48 Ginsburg was acknowledging, if not endorsing, the University's goal of enrolling a reasonably large number of minority students. Regardless of her interpretation, the plaintiffs and the justices who signed the majority opinion in Gratz definitively believed that the University's treatment of race in admissions was riddled with subjective bias and inaccuracy. The transparency of the University's policy, the plaintiffs' success at highlighting the contentiousness of race, the adjustability of the decision rules, and the involvement of outside authority of the Courtdrawing on the peculiar nature and conservative leanings of contemporary jurisprudence on race-contributed to a decision that ruled against the University's quantified decision-making.

The absence of debate over quantifying merit

Throughout the Gratz and Grutter litigation, there was relatively little contention over Michigan's reliance on quantified measures of merit (as the constitutionality of those measures was not in question). No one questioned whether merit could be quantified or whether SAT

\footnotetext{
${ }^{47}$ Gratz Majority Opinion, p. 4.
}

${ }^{48}$ Ginsburg's Dissent, p.8. 
scores and high school GPA, as quantitative measures of merit, should be considered in admissions. The legal participants treated these measures as reliable and objective and, therefore, legitimate bases for determining an applicant's qualification for admission. Justice Sandra Day O'Connor's concurring opinion in Gratz went so far as to describe non-academic factors as "soft" variables, reflecting the Court's presumption that quantified measures of merit were accurate and scientific.

In Gratz, quantified measures of merit were marshaled as objective facts of the matter to argue against the University's admissions policies. Critics contrasted the valuation of race and the valuation of merit to demonstrate the decisive advantage given to minority students. During oral arguments, Solicitor General Olson stated, "The 20 point bonus . . . is [equivalent to] one full grade point, nearly twice the benefit of a perfect SAT score. [E]very qualified candidate who gets the bonus gets into the University. It might just as well be an admissions ticket." During oral arguments, Justice Scalia went even further than this to suggest that race and merit were distinct categories at odds with one another. Scalia stated that the University could effortlessly admit more racial minority applicants with one simple change: "Just lower your qualification standards," he said to Payton. "You don't have to be the great college you are. You can be a lesser college if this value of [diversity] — of having everybody in a mix with people of other races is so significant to you." Scalia's statement presumed that the admission of the most meritorious students was in conflict with the pursuit of racial diversity. ${ }^{49}$

The University agreed that race and merit are distinct categories, but it argued that both were relevant for its objective of crafting an academically excellent, diverse student body. It also

\footnotetext{
${ }^{49}$ Some defenders of affirmative action later derided Scalia's statement as a racist, demeaning view of people of color as unintelligent. Brown-Nagin (2005: 804-805) observed that Scalia "uncritically accepted the plaintiffs' simplistic views of merit and their corresponding narrative of entitlement to admission."
} 
recognized some fuzziness between race and merit. Its brief referenced the "test score gap" between minorities and non-minorities, acknowledging that quantified measures of academic merit are correlated with racial group membership. Similarly, Ginsburg, in her dissenting opinion, noted the relationship between African-American and Hispanic status and low scores on standardized tests. ${ }^{50}$ But neither the University nor Ginsburg argued that this correlation made test scores an unreliable predictor of academic performance. Long gone was the 1960s University position that minority students could not be accurately judged by test scores.

In the Grutter litigation, a few participants attempted to problematize the quantification of merit. Political activists and Michigan students who intervened in Grutter at the Sixth Circuit Court of Appeals (although not at the Supreme Court), organized by the Coalition to Defend Affirmative Action and Integration and Fight for Equality By Any Means Necessary (BAMN), made a remedial argument for race-based affirmative admissions. They claimed that affirmative action is necessary not to achieve diversity but rather to offset racial discrimination in society at large and in current practices at the University and to proactively further the causes of equality and integration. ${ }^{51}$ In making this claim, the interveners posed a provocative argument about the University's quantification of merit: its "numerical admissions criteria" of GPAs and the LSAT were racially discriminatory. Citing social scientific research on bias in standardized test scores, the interveners noted that students' LSAT scores did not correlate with their later career success as lawyers. The gap between the scores of white students and those of black, Latino, and Native Americans, they claimed, was a product of "the cumulative effect of discriminatory tests, segregated education, social inequality, and the depressing effect of racial prejudice on the

\footnotetext{
${ }^{50}$ Ginsburg's Dissent, footnote 5.

${ }^{51}$ It is an argument that defendant organizations avoid, as it requires the organization to accept culpability for discrimination.
} 
undergraduate grades and overall academic performance of minority students. ${ }^{.52}$ At a January 2003 conference, BAMN organizer Shanta Driver posed the issue more bluntly: "The SAT and ACT are a racist lie."

Despite this punchy rhetoric, the arguments that the Grutter intervenors and BAMN activists made about the racism implicit in standardized tests were not central to the legal debates and did not impact the final decision. (The only other legal filings that criticized standardized tests and GPAs as measures of merit was an amicus brief submitted in Grutter by the American Sociological Association and four other organizations representing social scientists, in support of the University) ${ }^{53}$ Somewhat surprisingly, Justice Clarence Thomas, known for his conservative views, took a position similar to the interveners' in his separate dissenting opinion in Grutter, although to oppose affirmative admissions (Brown-Nagin 2005). Ultimately, though, quantified measures of merit remained largely taken-for-granted throughout these disputes, and their apparent objectivity and separation from race implied the possibility of race-blind admissions based solely on merit.

2003-2004: dequantifying diversity

The Supreme Court's decisions in Gratz and Grutter, announced on June 23, 2003, precipitated the dequantification of Michigan's undergraduate admissions policy. It ushered in a flurry of activity in the undergraduate admissions office. In consultation with lawyers, Regents, and University officials, OUA administrators finalized and implemented a new admissions policy for freshman applicants to the University's colleges and schools.

\footnotetext{
${ }^{52}$ Brief for respondents Kimberly James, et al, p. 5.

${ }^{53}$ Note: The authors of this paper are members of two of these organizations.
} 
The admissions process was, in fact, only partially dequantified. The OUA removed the quantitative decision rules used to mechanistically generate a decision and the quantitative inputs not directly related to academic merit. The most important change was the adoption of a qualitative review process. Every application would be read and assessed by two or three people, with each reader ultimately assigning a grade to the application. A subset of applications would be discussed in smaller committees, as well. All applications were ultimately approved by an enrollment working group.

The University made considerable efforts to make the new policy and procedures accessible to the public. In August 2003, the University of Michigan News Service issued a press release. ${ }^{54}$ It described Michigan's new process for gathering more information about applicants and its multiple layers of "highly individualized review," with commentary from the University president and provost stressing that the basic goals and priorities of the admissions process had remained the same. OUA's web site featured a page detailing the goals and steps of the new review process. The site outlined the procedures to be followed if reviewers disagreed about an application and detailed the "broad range of criteria" that readers and admissions counselors would consider.

Although the text of the new policy was widely advertised and made explicit, the actual decision-making process was not. Many parts of the new admissions policy read as cut-and-paste statements of the text of the Court's decision in Grutter. The opening of the policy stated:

Admissions is more art than science... With this new evaluation procedure, we have sought to further improve our process by finding better ways to ensure holistic, individualized review of the many facets of every application. Our new admissions program fosters such an individually-tailored review and decisionmaking process for each application by expanding flexibility and use of

\footnotetext{
${ }^{54}$ http://www.ns.umich.edu/index.html?Releases/2003/Aug03/admissions. Accessed June 4, 2015.
} 
professional judgment, while at the same time maintaining consistency in the way all applications are evaluated.

According to the policy, the review process would prioritize an applicant's academic achievements - GPA, test scores, courses taken, and high school environment — while still taking into account other qualities that would make him or her a successful student at the University. These qualities included "socioeconomic status, race or national origin, special skills and talents, [and] unusual life experiences." These guidelines entailed an important shift in the University's thinking about race. An applicant's race was no longer just a categorical designation-a check box to be marked. In the qualitative review process, race was also a cultural identity to be expressed. As the new policy stated, applicants needed to "demonstrate the ways in which they would contribute to the life and diversity of the University."

The qualitative review process required new inputs—namely, information about students' individual viewpoints, skills, and qualifications. The updated application was six pages longer than the previous version. The application still asked students about their race, although a new question asked if the applicant identified as multi-racial or multi-ethnic. Other new questions covered such topics as the applicant's financial responsibilities within their family, their grandparents' college attendance, and a choice of one of two questions about diversity (for an analysis, see Kirkland and Hansen 2011). The new application also included revised recommendation forms that gave high school teachers and guidance counselors expanded space to comment on a student's preparedness. Even so, the application and review process continued to rely on the quantitative measures of merit: standardized test scores and GPAs. It was dequantified, but never unquantified.

The new admissions procedures were so extensive that the undergraduate admissions office had to restructure its internal operations. OUA grew quickly from approximately 80 to 133 
employees, with between five and seven employees working a second shift. OUA first conducted two weeks of training workshops for 32 admissions counselors, staff, and outside application readers. In November 2003, OUA held a second, shorter training for additional application readers (attended by the second author as part of her fieldwork).

Under the new policy, each reviewer would grade an applicant according to a rating scale: outstanding, excellent, good, average/fair, and below average/poor. The training materials provided general descriptions and numerical ranges characterizing students in each of these categories. An "outstanding" student was described as having an SAT score between 1440 and 1600 (the highest possible score), as well as an essay that showed "superior writing ability." Each reviewer would make a recommendation based on his or her rating of the applicant. An "outstanding" student might be categorized as a "high admit" who should be considered for merit scholarships, while an "average" student's application might be labeled "deny with reservations" if they appeared qualified but had several deficiencies. The new policy still attempted to standardize decisions, but without rigid, formal, quantitative decision rules. Instead, the policy relied on training investigators to produce similar judgments by providing detailed examples. ${ }^{55}$ As the director of training explained, these descriptions and ranges were "just suggestions."

Although the policy's goals and the steps of the review process were widely publicized, the new ratings scale was not. On their applications, students still were asked to check boxes indicating their racial status, and they could write about race in their essays. But outsider observers could not readily tell what, exactly, the admissions office did with that information. The new qualitative process exemplified what some legal scholars characterized as a "don't tell, don't ask" regime of race-conscious decision-making (Ayres and Foster 2007). If transparency

${ }^{55}$ On trained judgment as a form of objectivity, see Daston and Galison 2007. 
was the hallmark of the points system, carefully managed opacity and vagueness characterized the new holistic assessment.

Thus, key aspects of the undergraduate admissions review process were dequantified following Gratz and Grutter. Instead of attempting to patch the points system or abandon affirmative action, the University abandoned its quantified decision-making rule. ${ }^{56}$ However, the new holistic review retained many of the same quantitative inputs: grades, and standardized test scores. Earlier acts of quantification thus remained vital to the admissions process, although in a more consultative fashion.

The University of Michigan was not the only higher education institution to alter its admissions practices in this period. The field of college admissions was changing. Several of Michigan's peer institutions, including the University of California, the University of Texas, and the University of Wisconsin, underwent fights over affirmative action in the 1980s and 1990s (Lipson 2001, 2011). These institutions all defended affirmative action (at least initially), and turned towards individualized admissions review in order to achieve diversity. In 2003, when Michigan began to implement its individualized review system, it examined the practices of its peer institutions as potential models for its own. Nonetheless, these field-level changes do not fully explain why the Supreme Court favored the law school's holistic review process in Grutter or why it rejected LSA's mechanical, quantified process in Gratz, and it was these decisions that spurred Michigan to dequantify affirmative action and admissions.

\footnotetext{
56 The Gratz decision did not require the elimination of the Selection Index, but rather the elimination of the quantification of racial categories. For example, we could imagine the University creating a review process that scored applicants' contribution to diversity on a scale from 0 to 20, and otherwise relying on all of the other, uncontested, quantifications in the Selection Index. Inside the University, however, such a move does not appear to have been considered: the University interpreted Gratz as saying that race could only be considered in a holistic framework, and there was not a major push to abandon race-conscious admissions.
} 
Summary

This evidence establishes the quantification and partial dequantification of affirmative action and admissions at Michigan. The political context and internal features of the University's system of quantification collectively contributed to this outcome. Because Michigan's quantified decision-making rule was simple to understand, requiring nothing more than basic arithmetic to critique, it created a relatively transparent window into admissions decision-making. That the system relied so heavily on fairly simple racial categorizations made it especially vulnerable because race itself was and remains contested and legally circumscribed. The transparency of the University's admissions process and the categorical valuation of race attracted the attention of anti-affirmative action activists, who had legal mechanisms to create a consequential challenge. Their litigation brought in the authority of the Supreme Court, which had legal jurisdiction over the use of race in college admissions. The transparency of the points system made it relatively easy for lawyers and judges - who were experts in the law but not in admissions or higher education - to understand the system, hone in on exactly how it treated race, and then argue about the merits of that treatment. Because the points system treated all members of underrepresented racial minorities as part of a unified category, a single kind of object, it conflicted with the legal rationale and rhetoric of diversity, which justified race-conscious decision-making only in terms of the unique contributions of individuals. The University's routine of admitting competitive students could be accomplished without a quantitative decision rule. Likewise, there existed viable, high-status, holistic alternatives for affirmative admissionsmost evidently, the law school's policy of holistic review, upheld in Grutter. In sum, given that 
challengers had a policy route to force change, the transparency of the quantified system, its reliance on a contested category, and the existence of qualitative alternatives to quantified decision-making all contributed to the weakness of the system.

\section{Discussion and conclusion}

We began our analysis by tracing the history of one decision-making practice, following undergraduate admissions at the University of Michigan as administrators made it more and then less mechanically quantified. Our objective is to improve scholarly understandings of the process of quantification and the relationship between quantification, dequantification, and rational, authoritative decision-making as well as the cultural processes that contribute to inequality. Our insights into the features and conditions that weakened Michigan's quantified admissions policy serve as a springboard for this discussion.

The Michigan case fits poorly into Porter's (1995) definitive account of quantification and decision-making. In his study of why quantification spread so widely in the $19^{\text {th }}$ and $20^{\text {th }}$ centuries, Porter demonstrates that decision-makers adopted quantification because it was less subjective and more mechanical. Subsequent scholarship has since emphasized the power of quantification, with its veneer of objectivity, to protect experts' judgment from external pressures (Espeland and Stevens 2008).

However, quantified decision-making did not inoculate the University of Michigan. If nothing else, the Michigan case offers a striking demonstration that quantification is not always more powerful than qualitative alternatives. Another clear conclusion of our study is that the relationship between quantification and decision-making is not binary. Social processes are not 
simply "quantitative" or "qualitative," but may rely on numbers to a greater or lesser degree. In turn, dequantification may be more or less partial.

By tracing the process of establishing and operationalizing affirmative admissions at Michigan, and then identifying the features of its system of quantification and the extenuating conditions that made the system vulnerable, our analysis also points to specific weaknesses of quantification. ${ }^{57}$ Considered separately, each of these features helps us to revise scholarly assumptions about the power of quantification to successfully produce authoritative, mechanically objective decisions (Espeland and Stevens 2008). Here we outline five insights that could be fruitfully extended by future research.

The first theoretical insight concerns the transparency of quantification. Transparent systems of quantification open their inner logics and routines to outside eyes, presenting opportunities for critics to challenge the system's construction. Transparency, like the other features we identified, is not an immutable fact of the world but the result of a complex social and political history. Quantification is commonly perceived as objective and impartial, but that perception depends on how open or closed the system is to outsiders' understanding and reinterpretation. ${ }^{58}$

Analogous dynamics around transparency are evident in the recent history of consumer credit scoring. Consumer credit scoring systems in the 1970s were readily legible. Congressional investigations led by critics of credit scoring uncovered the precise systems in use, and nonexperts openly debated the merits of the systems (Hyman 2011). Like Michigan's points system,

\footnotetext{
${ }^{57}$ We thank our anonymous reviewers for several helpful suggestions relevant to this discussion.

${ }^{58}$ Justice Ginsburg's dissent in Gratz suggests a more nuanced reading of the importance of transparency. Ginsburg explicitly argued that Michigan's transparency should be praised (as opposed to achieving the same effect through "winks, nods, and disguises"). But Ginsburg also supported a remedial justification for affirmative action, which the majority rejected. Thus, we see here transparency only served to weaken Michigan's policy in the face of criticism.
} 
some credit scoring systems explicitly categorized individuals by race, awarding more points to white borrowers. This explicit invocation of race was successfully banned through the Equal Credit Opportunity Act (as amended in 1976). The race of borrowers, along with gender and other protected classifications, was subsequently removed as an input in credit scoring. Since then, credit-scoring systems have also grown more complex. As the categories used have become less familiar, skeptics have faced increasing difficulty in organizing to challenge the systems (Simon 1988, Krippner 2013).

Our second theoretical insight concerns the social material that is the basis of quantification. Systems of quantification that rely on contentious categories may be less likely to acquire the legitimacy associated with objectivity. This reliance on unsettled categories can offer openings through which the quantification itself may be challenged. Conversely, our research suggests that a system of quantification may be seen as more legitimate, and thus be more resilient to challenges, when it relies on and makes commensurate categories that have very little social or political salience and are taken for granted or simply unknown.

Credit scoring again illustrates this point nicely. Once credit scores were cleansed of their explicit reliance on the contested categories of race and gender, they became sufficiently credible to use as the basis for automated systems of mortgage underwriting (Straka 2000, Stuart 2003). Regulators concerned with issues of redlining and other forms of racial discrimination agreed that automated processes that explicitly excluded information about race were more likely to be fair and objective than the older, more holistic forms of assessment.

Third, for systems of quantification tightly linked to specific decision-making practices, the policy routes available to challengers can become highly relevant. Challengers may have avenues to appeal to authorities at different levels, from leaders within an organization (such as a 
university president) to external authorities with sufficient capacity to impose changes. Courts are an obvious and pervasive outside authority to which challengers of a system of quantification might potentially appeal, although the U.S. Congress, the president, and governors can exercise tremendous influence as well. Their own rules, standards, norms, expertise, and reputational concerns would likely be important factors shaping the possibility of dequantification.

The membership rules used by Native American tribes clearly illustrate this point. Many Native American tribes in the United States rely on a quantified system to determine tribal membership, called "blood quanta" rules (Gover 2008, 2010). These rules grant membership (on which voting rights and a range of economic and legal benefits rely) to anyone who is a close enough relative to a tribal member, with the exact quanta (degree of relationship) varying by tribe. Today, the membership requirement for a tribe tends to be somewhere between one-half degree blood quantum (one parent) to one-sixteenth degree (a great-great grandparent) (Gover 2008). These rules are both transparent and contentious. Predictably, these practices have been subjected to many challenges. Due to the sovereign status of tribes, the primary policy route to changing the membership rules is through a popular vote among members, and these challenges have had little success (e.g., ICTMN 2003). Disputes are within tribal nations and concern their own rules of membership, so there is no outside political authority that can force changes on the tribes (Spruhan 2006).

Fourth, dequantification of a routine, practice, or process appears to be abetted by the existence of a non-quantitative alternative. It is plausible that the very existence of viable alternatives would inform debates over quantification. Future research should examine whether an outside authority could force a change without a viable alternative. We expect that, at best, the 
outside authority could force an end to the practice entirely - but as noted at the outset, this is not the same as dequantifying the practice.

Potential cases for further study, in which alternatives to quantification are lacking, could include those involving monetary compensation. For example, Zelizer (1985) shows how challenges to the economic valuation of children's lives in the early twentieth century resulted in a change in the basis on which monetary damages were calculated (from a standard involving the economic loss of the child to one emphasizing the emotional damage to the parents), but not the elimination of damages entirely. Similarly, Fourcade (2011) traces various attempts to quantify the damage done to nature by oil spills for the purpose of assessing damages to oil companies in lawsuits. French and American experts relied on different techniques, from measures of the commercial value of destroyed wildlife to contingent valuation surveys of lost enjoyment of damaged beaches. Despite the contentiousness of each method, some quantification was inevitable - there is simply no legitimate qualitative alternative to monetary damages.

Fifth, and finally, for decisions that generate an outcome that is one point on a range ("how much"), some aspect of the decision-making routine must be quantified. Here, some form of quantification is inevitable. On the other hand, for decisions that generate a categorical outcome ("yes/no"), there exists at least the possibility of the complete elimination of quantified decision-making. In these instances, quantification is a possible, but not necessary, form of rationalization. Thus, organizational decision-making practices that produce "yes/no" decisions rather than "how much" will likely be more useful cases for understanding the limits of quantification.

Although our primary focus has been explaining the significance of our case for theories of the power of quantification, our findings also speak to the potential for quantification to serve 
as a tool for ameliorating inequality. As Lamont et al. (2013) argue, cultural practices of rationalization (including quantification) are key components in the production, reproduction, and potential alleviation of inequality. Rationality, as Weber (1922) argued, is closely associated with notions of merit. Michigan's grids and points system made academic merit explicitly commensurate with race: one point of GPA was made "equivalent" to belonging to an underrepresented minority group. While academic merit squared neatly with the underlying logic of rationalization, race did not. The system's treatment of race was irrational in that it violated the implicit logic of neutrality that is a hallmark of standardization. The logic of diversity that Michigan had adopted in the 1980s seemed to justify the treatment of individuals as unique and unclassifiable, but the actual practices of the Office of Undergraduate Admissions homogenized individuals as members of large, contentious, categories. More broadly, our case suggests that the quantification of decision-making seems likely to conflict with anti-inequality interventions that employ criteria of redistributive justice. In our case, we saw the University of Michigan relying on elaborate decision-making routines and rationales to manage the tensions around interventions intended to be both meritorious and equalizing.

Quantification is a process that admits to degrees. For better or for worse, systems of quantification vary in their ability to transform decisions into uncontestable exercises of seemingly objective procedures. Quantification, despite its manifold successes, is thus neither inevitable nor irreversible.

\section{Acknowledgments}

We thank Emily Bosk, Jamie Budnick, John Carson, Tony Chen, Russ Funk, Gabrielle Hecht, Steve Hoffman, Greta Krippner, Kathy Lin, John Mohr, Jason Owen-Smith, Michelle Phelps, Rachael Pierotti, Elizabeth Young, and audiences at the Economic Sociology Workshop and the Science, Technology, and Society Colloquium at Michigan, the Society for Social Studies of Science in Cleveland, and the American Sociological Association in Denver for helpful 
comments on earlier versions of this work. This work was supported by the American Bar Foundation; the National Science Foundation [Grant No. 0418547]; the Northwestern University Center for Legal Studies; and the Northwestern University Graduate School.

\section{Bibliography}

Alder, Ken 2002. The Measure of All Things. The Free Press.

Anderson, Elizabeth 2002 "Integration, Affirmative Action, And Strict Scrutiny." New York University Law Review 77:1195-1271

Ayres, Ian, and Syndey Foster. 2007. "Don't Tell, Don't Ask: Narrow Tailoring after Grutter and Gratz." Texas Law Review 85(3):517-583.

Beckert, Jens, and Patrik Aspers. 2011. The Worth of Goods: Valuation and Pricing in the Economy. Oxford University Press, USA.

Berrey, Ellen C. 2011. "Why Diversity Became Orthodox in Higher Education, and How It Changed the Meaning of Race on Campus." Critical Sociology 37(5):573-596.

Berrey, Ellen C. 2015. The Enigma of Diversity. University of Chicago Press.

Bowker, Geoffrey C., and Susan Leigh Star. 2000. Sorting things out: classification and its consequences. MIT Press.

Brown-Nagin, Tomiko. 2005. "The Transformative Racial Politics of Justice Thomas?: The Grutter V. Bollinger Opinion," University of Pennsylvania Journal of Constitutional Law: 7(3): 787-807.

Brune, S. 1994. "Conflict and Conciliation: A review of the Black Action Movement strike at the University of Michigan.” Michigan Journal of Political Science 5: 39-66.

Burawoy, Michael. 1998. "The extended case method." Sociological Theory 16(1):4-33.

Callon, M. 1998. "An essay on framing and overflowing: economic externalities revisited by sociology.” Pp. 244-269 in The Laws of the Markets. Wiley-Blackwell.

Christin, Angele. 2015. "Counting Clicks: Quantification and Commensuration in Online Journalism in the United States and France." Working paper.

Daston, Lorraine J., and Peter Galison. 2007. Objectivity. Zone.

Douglas, Mary. 1986. How Institutions Think. Syracuse University Press.

Espeland, Wendy N. 1998. The Struggle for Water. University Of Chicago Press. 
Espeland, Wendy. 2009. "Thinking about Standards in Qualitative Research." in Workshop on Interdisciplinary Standards for Systematic Qualitative Research, edited by Michele Lamont and Patricia White. Washington, DC: National Science Foundation, pp. 65-68.

Espeland, Wendy Nelson, and Mitchell L. Stevens. 1998. "Commensuration as a Social Process." Annual Review of Sociology 24:313-343.

Espeland, Wendy Nelson, and Mitchell L. Stevens. 2008. "A Sociology of Quantification." European Journal of Sociology 49(03):401-436.

Espeland, Wendy Nelson, and Michael Sauder. 2007. "Rankings and Reactivity: How Public Measures Recreate Social Worlds." American Journal of Sociology 113(1):1-40.

Espeland, Wendy Nelson, and Berit Irene Vannebo. 2007. "Accountability, Quantification, and Law.” Annual Review of Law and Social Science 3(1):21-43.

Foucault, Michel. 1994. The Order of Things. Vintage.

Fourcade, Marion. 2011. "Cents and Sensibility: Economic Valuation and the Nature of 'Nature'." American Journal of Sociology 116(6):1721-77.

Garfinkel, Harold. 1967. Studies in Ethnomethodology. Englewood Cliffs, NJ: Prentice-Hall. Gerring, John. 2006. Case Study Research: Principles and Practices. Cambridge University Press.

Gerring, John. 2009. "What Standards Are (or Might be) Shared?" in Workshop on Interdisciplinary Standards for Systematic Qualitative Research, edited by Michele Lamont and Patricia White. Washington, DC: National Science Foundation, pp. 107-123.

Glaser, Barney G., and Anselm Strauss. 1967. The Discovery of Grounded Theory. Weidenfeld and Nicolson.

Goffman, E. 1974. Frame Analysis. Harper \& Row.

Gover, Kirsty. 2008. "Genealogy as Continuity: Explaining the Growing Tribal Preference for Descent Rules in Membership Governance in the United States." American Indian Law Review 33(1):243-309.

Gover, Kirsty. 2010. "Comparative Tribal Constitutionalism: Membership Governance in Australia, Canada, New Zealand, and the United States." Law \& Social Inquiry 35(3):689-762.

Graeber, David. 2001. Toward An Anthropological Theory of Value. Palgrave Macmillan.

Greenland, Fiona R., Anthony S. Chen and Lisa M. Stulberg. 2010. "Beyond the Open Door: The Origins of Affirmative Action in Undergraduate Admissions at Cornell and the University of Michigan." Paper presented at the Policy History Conference, June 4, 2010, Columbus, OH. 
Hacking, Ian. 1982. "Biopower and the Avalanche of Printed Numbers." Humanities in Society 5(3/4):279-295.

Hacking, Ian. 2005. "Why race still matters.” Daedalus 134(1):102-116.

Haydu, J. 1998. "Making Use of the Past: Time Periods as Cases to Compare and as Sequences of Problem Solving." American Journal of Sociology 104(2):339-371.

Hirschman, Daniel. 2015. "Inventing the Economy (or, How We Learned to Stop Worrying and Love the GDP).” Ph.D Dissertation.

Hochschild, JL. 2002. "Affirmative action as culture war." In A Companion to Racial and Ethnic Studies, edited by David Goldberg and John Solomos, pp. 282-303. Wiley-Blackwell.

Holm, Petter. 2007. "Which way is up on Callon?” In MacKenzie, Donald, Fabian Muniesa, and Lucia Siu Do Economists Make Markets?, pp. 225-243. Princeton University Press.

Huault, Isabelle, and Hélène Rainelli-Weiss. 2011. "A Market for Weather Risk? Conflicting Metrics, Attempts at Compromise, and Limits to Commensuration." Organization Studies 32(10):1395-1419.

Hyman, Louis. 2011. Debtor Nation. Princeton University Press.

ICTMN (Indian Country Today Media Network). 2003. "Blood quantum wins at Flathead; membership decline predicted." Jan. 24.

Jasanoff, Sheila. 1991. “Acceptable Evidence in a Pluralistic Society.” In Mayo, D. \& R. Follander Acceptable Evidence: Science and Values in Risk Management, pp. 29-65. Oxford University Press.

Karabel, Jerome. 2005. The Chosen. Houghton Mifflin Harcourt.

Killgore, Leslie. 2009. "Merit and Competition in Selective College Admissions." The Review of Higher Education 32(4):469-488.

Kirkland, Anna and B.B. Hansen. 2011. “'How Do I Bring Diversity?' Race and Class in the College Admissions Essay." Law \& Society Review 45(1):103-138.

Krippner, Greta R. 2013. "Possessive Collectivism: Ownership and the Politics of Credit Access in Late-Twentieth Century America." University of Michigan.

Lamont, Michèle. 2012. "Toward a Comparative Sociology of Valuation and Evaluation." Annual Review of Sociology 38(1):201-221.

Lamont, Michele, Stefan Beljean, and Matthew Clair. 2013. "What is Missing? Cultural Processes and Pathways to Inequality." Socioeconomic Review.

Latour, Bruno. 2007. Reassembling the Social. Oxford University Press.

Lemann, Nicholas. 1999. The Big Test: The Secret History of the American Meritocracy. Farrar, Straus and Giroux. 
Lipson, Daniel N. 2001. "Affirmative Action as We Don't Know It: The Rise of Individual Assessment in Undergraduate Admissions at UC-Berkeley and UT-Austin." Studies in Law, Politics and Society 23:137-184.

Lipson, Daniel N. 2011. "The Resilience of Affirmative Action in the 1980s: Innovation, Isomorphism, and Institutionalization in University Admissions.” Political Research Quarterly 64(1):132 -144.

Luker, Kristin. 2008. Salsa Dancing into the Social Sciences. Harvard University Press.

MacLean, Nancy. 2006. Freedom Is Not Enough: The Opening of the American Workplace. New York: Russell Sage Foundation

Marron, Donncha. 2007. "'Lending by numbers': credit scoring and the constitution of risk within American consumer credit." Economy and Society 36(1):103-133.

Nelson, Bryce. 1967. "Ruckus over Race Has Relevance to Other Universities." Science 156 (3779):1209-1212.

Nelson, Robert L., Ellen Berrey, and Laura Beth Nielsen. 2008. "Divergent Paths: Conflicting Conceptions Of Employment Discrimination In Law And The Social Sciences." Annual Review of Law and Social Science 4:103-122.

Omi, Michael and Howard Winant. 1994. Racial Formation in the United States. Routledge.

Pentland, Brian T., and Martha S. Feldman. 2005. "Organizational routines as a unit of analysis." Industrial and Corporate Change 14(5):793 -815.

Pfeffer, Jeffrey, and Gerald R Salancik. 1978. The External Control of Organizations: $a$ Resource Dependence Perspective. New York: Harper \& Row.

Poon, Martha. 2007. "Scorecards As Devices For Consumer Credit: The Case Of Fair, Isaac \& Company Incorporated." The Sociological Review 55:284-306.

Porter, Theodore M. 1995. Trust in Numbers: The Pursuit of Objectivity in Science and Public Life. Princeton University Press.

Prewitt, Kenneth. 2005. "Racial Classification In America: Where Do We Go From Here?" Daedalus Winter:5-17.

Sauder, Michael, and Wendy Nelson Espeland. 2009. "The Discipline of Rankings: Tight Coupling and Organizational Change." American Sociological Review 74(1):63 -82.

Simon, Jonathan. 1988. "The Ideological Effects of Actuarial Practices.” Law \& Society Review 22(4):771-800.

Skrenty, John David. 1996. The Ironies of Affirmative Action. University of Chicago Press.

Skrentny, John David. 2002. The Minority Rights Revolution. Harvard University Press. 
Small, Mario. 2009. "'How many cases do I need?': On science and the logic of case selection in field-based research." Ethnography 10(1):5-38.

Spruhan, Paul. 2006. “A Legal History of Blood Quantum in Federal Indian Law to 1935.” South Dakota Law Review. 51:1-50.

Stapleford, Thomas A. 2009. The Cost Of Living In America: A Political History Of Economic Statistics, 1880-2000. Cambridge: Cambridge University Press.

Steinberg, Jacques. 2002. The Gatekeepers: Inside the Admissions Process of a Premier College. Penguin Books.

Stevens, Mitchell L. 2009. Creating a Class: College Admissions and the Education of Elites. Harvard University Press.

Stinchcombe, Arthur L. 2005. The Logic of Social Research. University of Chicago Press.

Straka, J. W. 2000. "A Shift in the Mortgage Landscape: The 1990s Move to Automated Credit Evaluations.” Journal of Housing Research 11(2):207-232.

Stuart, Guy. 2003. Discriminating Risk: The U.S. Mortgage Lending Industry in the Twentieth Century. Cornell University Press.

Stulberg, Lisa M., and Anthony S. Chen. 2014. "The Origins of Race-conscious Affirmative Action in Undergraduate Admissions: A Comparative Analysis of Institutional Change in Higher Education." Sociology of Education 87(1):36-52.

Thelin, J.R. 2004. A History of American Higher Education. Johns Hopkins University Press.

Weber, Max. 1922 [1978]. Economy and Society. University of California Press.

Weber, Max. 1958 [2001]. The Protestant Ethic and the Spirit of Capitalism. Routledge.

Zelizer, Viviana. 1985. Pricing the Priceless Child. Basic Books.

Zwick, Rebecca. 2004. Rethinking the SAT. Psychology Press. 
Figure 1: 1996 SCUGA decision grid for in-state students. The letters in each cell refer to an admissions decision - "A" is accept, decisions starting with "r" are rejections (e.g., "rtst" is a rejection for low test scores). Source: Admissions Lawsuit Collection, Box 14, file: "Defendant Motions", Bentley Historical Library.

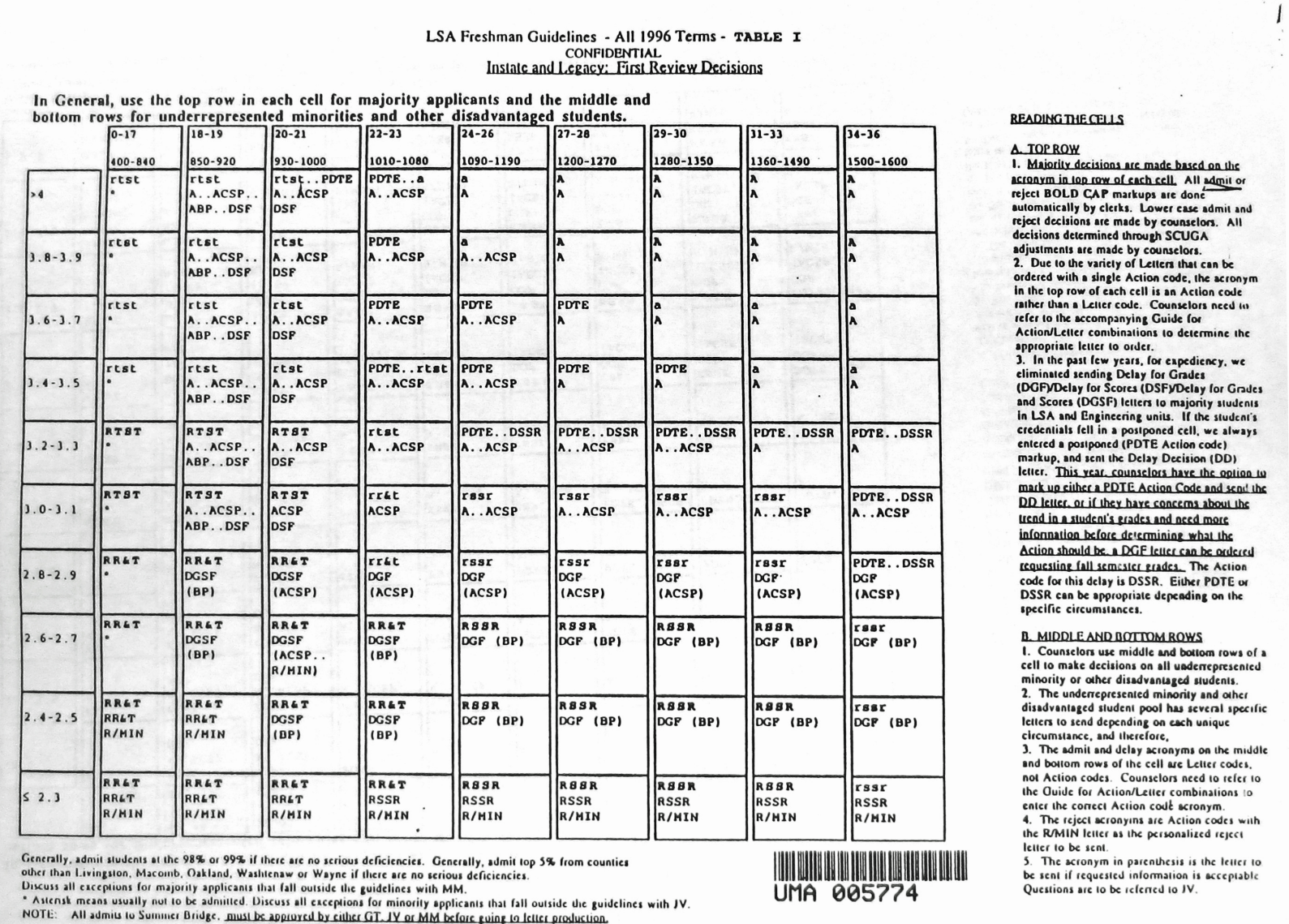


Figure 2: 1998 Selection Index Worksheet. 100 points were needed to secure admission. Source: Admissions Lawsuit Collection, Box 14, file: "Defendant Motions", Bentley Historical Library.

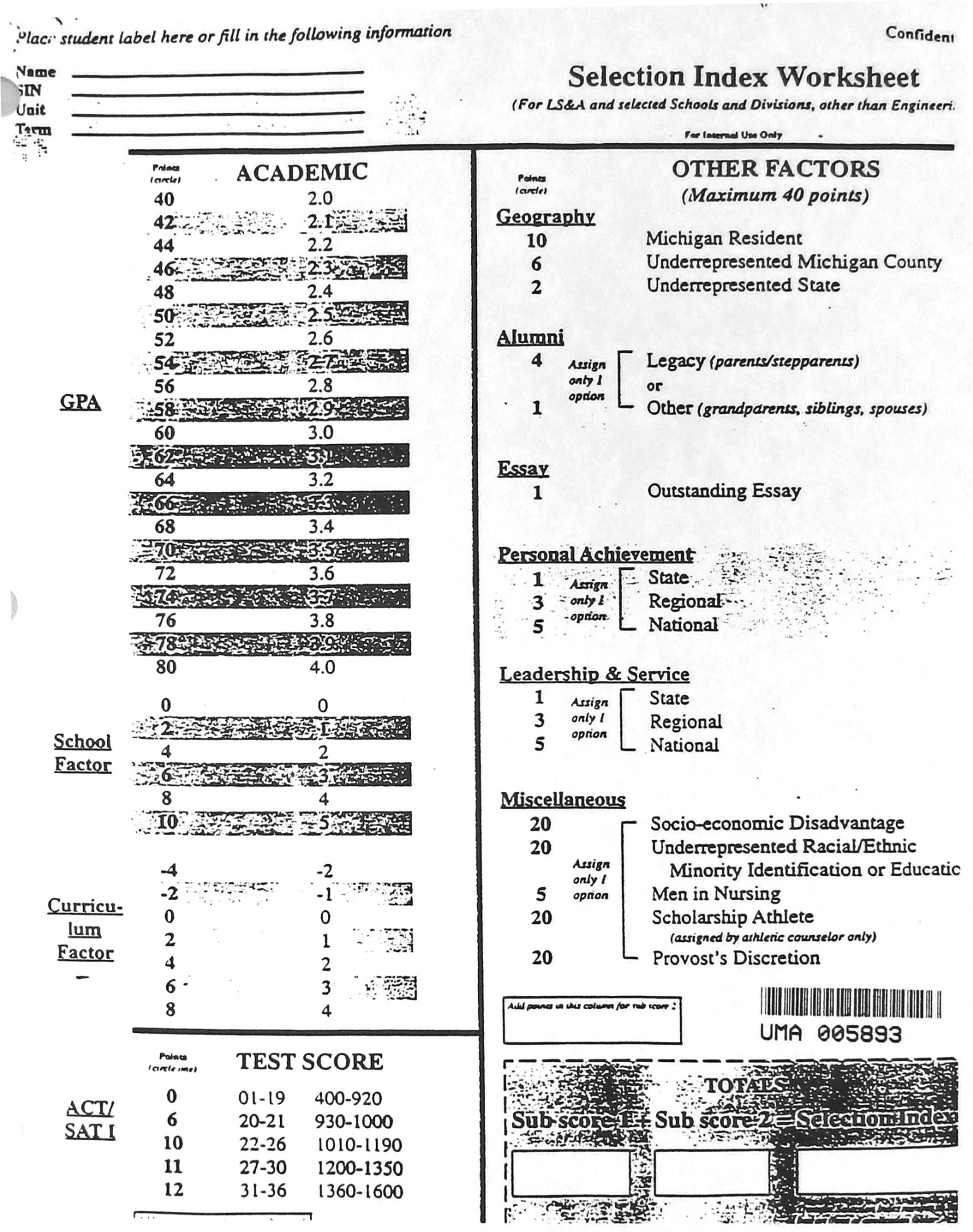

